\title{
PLANNING CAPACITY OF SLOVENIAN MUNICIPALITIES
}

\section{UPRAVLJAVSKA SPOSOBNOST SLOVENSKIH OBCIN NA PODROČJU PROSTORSKEGA NACRTOVANJA}

Naja Marot

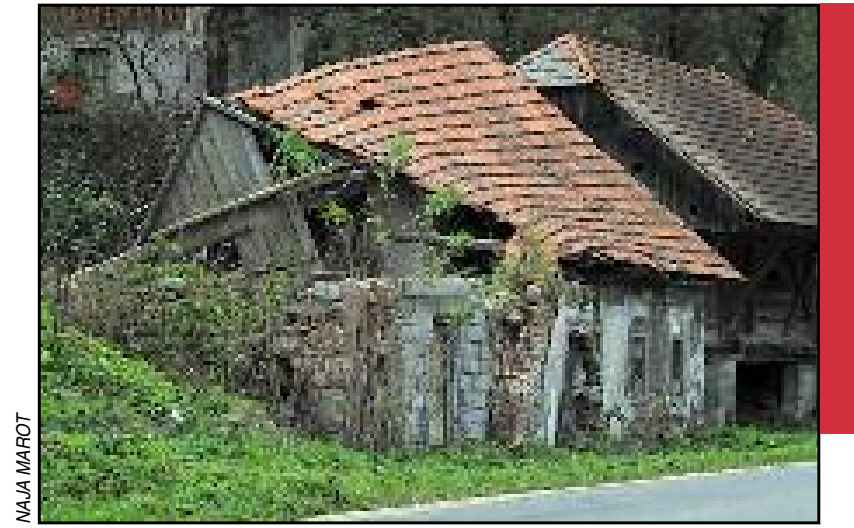

Spatial development as steered by the legislation?

Prostorski razvoj - posledica prostorske zakonodaje? 


\title{
Planning capacity of Slovenian municipalities
}

DOI: $10.3986 /$ AGS50106

UDC: 71:352(497.4)

COBISS: 1.01

\begin{abstract}
Spatial planning is one of the major legal duties for Slovenian municipalities. The planning framework is legally defined in the Spatial Planning Act which is frequently modified. Thus, municipalities need to adhere to changes very often. The capability of a municipality to adapt to new obligations and conditions influences delivery of spatial development. In a doctoral research we analyzed the capacity of municipalities to implement the planning act, i.e. what is the planning governance capacity of Slovenian municipalities. Thirteen indicators were defined and data were collected with the help of a questionnaire and secondary sources. These indicators were then used to produce the typology of management capacity in the field of planning. We also tested whether the size and spatial characteristics of a municipality affected the final result of this classification. Fifty-five municipalities were classified into three groups: municipalities with poor conditions for the implementation of spatial planning legislation (37 municipalities), municipalities with fair conditions for the implementation of spatial planning legislation (17 municipalities) and the Municipality of Ljubljana as the municipality with the best conditions. Groups differ in human resource solutions, finance consumption, frequency of participation of stakeholders and their impact. Comparison between the size and typology of governance showed their mutual dependence, and therefore in different sized municipalities we find different governance capacities. Finally, some suggestions for better spatial governance are proposed.
\end{abstract}

KEY WORDS: geography, spatial planning, municipalities, cluster analysis, governance, Slovenia.

The article was submitted for publication on May 24, 2010.

\section{ADDRESS}

Naja Marot, Ph. D.

Urban Planing Institute of the Republic of Slovenia

Trnovski pristan 2, SI - 1127 Ljubljana, Slovenia

E-mail: naja.marot@uirs.si

\section{Contents}

1 Introduction 133

2 Methodology 134

3 Results by selected indicators 138

$4 \quad$ Municipality typology 143

5 Conclusion 145

6 References 146 


\section{Introduction}

Spatial planning is one of the main responsibilities of Slovenian municipalities (ZLS-UPB2 2007). Municipalities and local communities provide a quality living environment, utility and transportation infrastructure, protect the environment, manage municipal assets, implement land policy and otherwise care for the land. For the task of planning, therefore, at least one person is needed. According to the old Spatial Planning Act (ZUreP-1 2003) it was a municipal town planner, but according to the new Spatial Planning Act (ZPNačrt 2007) that is no longer mandatory, even though the table on the validity of articles of the old and the new law says otherwise (MOP 2010; Due to frequent use, the following abbreviations are used in the article: ME - Ministry of Economy, MPA - Ministry of Public Administration, MESP Ministry of the Environment and Spatial Planning, MAFF - Ministry of Agriculture, Forestry and Food, MT - Ministry of Transport, NGOs - nongovernmental organizations, RDA - Regional Development Agency, OECD - Organisation for Economic Cooperation and Development, MSP - municipal spatial plan, GORP Government Office for Local Self-Government and Regional Policy, SORS - Statistical Office of the Republic of Slovenia).ZPNačrt (2007) did not produce new solutions that would provide greater spatial governance, although the situation in the planning system was very poor (Gerbec 2003; Pogačnik 2007; Zavodnik Lamovšek 2003; Marot 2011). Staffing is only one of the indicators to evaluate the implementation of spatial planning legislation, which was also named management ability.

Planners or developers often face the management capacity in the process of preparing spatial planning legislation, executive act or during the course of its implementation, when they are confronted with certain obstacles and reach the expected targets more slowly than expected. In Slovenia a large number of records on issues of spatial legislation implementation and situation analysis can be found, for example, already Mušič (1978) refers to a comparative study of foreign and domestic spatial legislation that was to help prepare the next spatial legislation of 1984. In the 1990s, the Ministry of the Environment and Spatial Planning conducted a comprehensive survey, but data were not processed to the needs of assessing spatial planning. Recent extensive studies were conducted by Blagajne and Šantej (2001) and Ravbar and Bole (2002). The first two are at the Institute of environmental law by means of a questionnaire carried out in the municipalities and administrative units, to obtain information about the capacity, the process of adopting the acts, municipal planning problems and possible solutions and proposals to the contractor. Ravbar and Bole (2002) focused more on the planning system as a whole. Broad-based survey on human resources and organizational aspects are inter-municipal cooperation and introduction of business principles in the functioning of municipal administration on the sample of 118 municipalities was performed at the Faculty of Social Sciences (Ferfila 2008). The findings of all the studies are similar - most municipalities have a unified administration, municipalities have poor human resources and are in need of additional staff, financial resources for spatial planning are on the decline (Ravbar and Bole 2002; Marot 2010), and the public participation is still very limited (Golobič and Marušič 2007). In 2009, the Chamber of Architecture and Spatial Planning prepared a short questionnaire in which $60 \%$ of respondents reported that changes in legislation and unsettled conditions in the planning hindered their work (Cimolini and others 2009).

The conducted research covered some aspects of land management, but their conclusions were only partly included in the process of drafting new legislation. The process of development, the involvement of operators in it and the assessment of the impacts of legislation are regulated by the Rules of procedure of the Government of the Republic of Slovenia (2001) and The National Assembly of the Republic of Slovenia Rules of Procedure (2002). According to the Rules of Procedure of the Government financial implications of the draft of the act have to be assessed, all data and information needed for decision making must be prepared, and all the relevant ministries and government offices present their opinions. Based on regulatory impact assessment (RIA), introduced by the OECD the 1980s, and adopted by the European Union in its 2001 White Paper on Governance (2001), Slovenia, like most other European countries opted for the reduced version of the assessment, termed the initial impact assessment. Rating regulation puts emphasis on the reduction of bureaucratic obstacles to the creation and operation of businesses, increasing transparency of operating conditions, and transparency of public administration and spending (Ministrstvo za javno upravo 2005). Although public participation is emphasized, the opinion of individuals often has little bearing on the final regulation. This was demonstrated in the preparation of the latest spatial planning legislation, where organized public, despite its good coordination, could not prevent the adoption of inappropriate regulation (DURS and others 2007). The main method of collecting information is a ques- 
tionnaire, but is not intended for making broad, including a content-wise assessment of the state of management of the field. The latest framework for assessing the environment for the implementation is the Resolution on Legislative Regulation (2009). The necessary level of management capacity is to be ensured by preliminary in-depth analysis of problems, clearly defined objectives, assessment of the justification and appropriateness of the regulation and possible simplifications. Despite, in principle, the system set up to prepare regulations that require prior review, the practice is different, with the example of the latest spatial planning regulations - ZPNačrt (2007). In a study on the process of drafting legislation the Legal Information Centre for NGOs and Umanotera (2007) found that while the drafters ensured the participation of the interested public in the earliest stages of preparation of spatial legislation and presented various solutions of content, they did not commission expert bases for assessing the actual state of the system, in which the new legislation will be implemented, or give feedback on the proposals.

Less emphasis on the integration of contractors in the preparation of regulations speaks contrary to the findings of Black (2002), who states that effective regulation is not dependent on the power of the regulator, but the attitude of the legislator to legislation and vice versa. If the legislator wishes to ensure the successful implementation of legislation, they must take into account the state of the system - working principles and values of stakeholders, the wider institutional environment, a different logic of regulatory tools and strategies - and changes of any part of the system (Igličar 2004). Based on the state of the system, the legislative process set-up and current practices were assessed by analysis of the state to find out the management capacity for spatial planning. The feasibility assessment is only one part of the otherwise broad-based study aimed at an integrated assessment of spatial legislation (Marot 2010).

\section{Methodology}

In the design of the method we derived from a variety of assessment methods with the aim of designing analysis, which will include its operators. We relied on the method of RIA (Regulatory Impact Assessment), which represents "an internationally recognized analytical and communication tool, which in the past two decades has been used worldwide in public administration in order to eliminate unnecessary regulations and improve the quality and implementation of regulations" (Kovač 2005; Rakar 2003; OECD 2005). Additionally, we drew from Social Impact Assessment, which measures the impacts of selected policy/regulation on the management, good administration and public participation (Majchrzak 1987). The broad-based method of assessment includes six criteria (comprehensibility, feasibility, efficiency/effectiveness, legitimacy, transparency and openness, and sustainability; The following references were used to define criteria for good legislation: Cerar 2006; CEC 2001; CEC 2002; Fink-Hafner and Lajh 2002; Jacobs in: Kirkpatrick and Parker 2007; Klančišar 2006; Klenovšek 2003; Ministrstvo za javno upravo 2005; OECD 2005. The following references were used to define criteria for good legislation: Cerar 2006; CEC 2001; CEC 2002; Fink-Hafner and Lajh 2002; Jacobs in: Kirkpatrick and Parker 2007; Klančišar 2006; Klenovšek 2003; Ministrstvo za javno upravo 2005; OECD 2005.), further evaluated by means of indicators; in this paper the findings by selected indicators are combined into a transparent typology of management capacity. We selected thirteen indicators of management capacity (see Table 1), which measure the adequacy of criteria for the establishment of a municipality and the establishment of a municipality by secession, the adequacy of human resource solutions and the need for additional staff, available finances, problems understanding the legislation that affect the implementation, the level of public participation and the impact, frequency and quality of participation of different population groups.

The survey questionnaire was answered by 55 out of 210 municipalities, $26 \%$, covering $6946 \mathrm{~km}^{2}-$ $34 \%$ of Slovenian territory and with the population of 891,676 as of $30^{\text {th }}$ June $2009-44 \%$ of the population of Slovenia. The smallest municipality was Miklavž na Dravskem polju $\left(12.5 \mathrm{~km}^{2}\right)$, and the largest Tolmin with $381.5 \mathrm{~km}^{2}$. Population-wise the smallest one was Ribnica na Pohorju $(1,246)$, and the largest one with the population of 278,314 urban municipality Ljubljana (SURS 2010). The most municipalities were in Pomurska (9), Podravska (8) and Osrednjeslovenska (7) regions. A comparison of the sample with the entire population - all Slovenian municipalities - showed that the sample corresponds to the population by type of municipality and the administration pattern; the differences are in the area, population categories distribution and achieving the statutory limit, where the sample has a smaller share of municipalities below the legal limit than the population. Thus we can conclude that in the case of 55 select- 
Table 1: Indicators used for measuring managing capacity.

\begin{tabular}{|c|c|c|}
\hline Indicator & Indicator description, references & Measuring / categories \\
\hline $\begin{array}{l}\text { Establishment of a municipality } \\
\text { by secession }\end{array}$ & $\begin{array}{l}\text { municipality was formed by secession after } \\
1993 \text { - a potential change in spatial planning } \\
\text { management capacity, SORS, data on territorial } \\
\text { organization }\end{array}$ & yes/no \\
\hline $\begin{array}{l}\text { Meeting the legal criteria } \\
\text { of a minimum number of county } \\
\text { residents for establishment }\end{array}$ & $\begin{array}{l}\text { community meets/does not meet the legal } \\
\text { criteria; SORS, the data on the population of the } \\
\text { municipality at the time of the establishment }\end{array}$ & $\begin{array}{l}\text { - above the basic population minimum }(5,000) \\
\text { - between the conditional population } \\
\text { minimum }(2,000) \text { and the basic } \\
\text { population minimum }(5,000) \\
\text { - below the conditional population } \\
\text { minimum }(2,000)\end{array}$ \\
\hline Type of administration & $\begin{array}{l}\text { type of administration in each municipality; } \\
\text { GORP, additionally telephone interview, } \\
\text { Martič (2002) }\end{array}$ & $\begin{array}{l}\text { - unified administration (without internal division) } \\
\text { - divided administration }\end{array}$ \\
\hline $\begin{array}{l}\text { Internal organization of the } \\
\text { municipal administration } \\
\text { in the field of spatial planning }\end{array}$ & $\begin{array}{l}\text { organizational arrangements within the } \\
\text { municipal administration in the field of } \\
\text { spatial planning, questionnaire }\end{array}$ & $\begin{array}{l}\text { - no department of the environment and spatial } \\
\text { planning } \\
\text { - department of the environment and spatial } \\
\text { - planning } \\
\text { - office of planning and environmental protection } \\
\text { - office of spatial planning } \\
\text { - joint spatial planning administration }\end{array}$ \\
\hline
\end{tabular}

\begin{tabular}{lll}
\hline Own municipal town planner & $\begin{array}{l}\text { the existence of a person who covers the field } \\
\text { of planning, after hearing the SPA-1 (2003) } \\
\text { questionnaire }\end{array}$ & yes/no \\
\hline Share of municipal
\end{tabular}

Share of municipal budget share of spatial planning spending in the overall spending on spatial planning budget - item 062 in the COFOG classification, $\%$ 2008; Ministry of Finance, own calculations (COFOG - Classification of the Functions of Government. The category of municipalities' spending "housing industry and local community services « has a subcategory of spatial planning, which includes the management of spatial development of local communities, implementation of laws and regulations governing spatial planning and construction, planning new or renovating old neighbourhoods and others; Ministrstvo za finance 2010).

Difficulty understanding the existence of problems of spatial planners the ZPNačrt in understanding the law; questionnaire

a) No problems understanding the terms and wording of the legislation.

b) The text of the act is unclear and complicated. (Conceptual understanding)

c) The text of the act is difficult to read. (Stylistic understanding)

č) The functions and duties of municipalities are not consistently (uniquely) defined.

d) The distribution of tasks between different administrative levels is unclear.

e) The terms used for specific concepts or spatial phenomena are not appropriate. Multiple answers possible.

\begin{tabular}{lll}
\hline $\begin{array}{l}\text { Assessment of the adequacy } \\
\text { of human resources for planning } \\
\text { by municipalities }\end{array}$ & numerical estimate of the adequacy of human & 1 - totally inadequate \\
& & $2-$ inadequate \\
& & $3-$ partially adequate \\
& & $4-$ adequate \\
& & $5-$ very appropriate \\
\hline \multirow{2}{*}{$\begin{array}{l}\text { The number of employees } \\
\text { in the municipality for planning planning, questionnaire }\end{array}$} & number of employees engaged in a planning, & absolute number \\
\cline { 1 - 2 } & questionnaire & \\
\hline
\end{tabular}




\begin{tabular}{|c|c|c|}
\hline The need for new jobs & $\begin{array}{l}\text { there is a need for new job posts in the field } \\
\text { of planning, also a description; questionnaire }\end{array}$ & yes/no \\
\hline $\begin{array}{l}\text { Impact of population groups } \\
\text { on spatial development }\end{array}$ & $\begin{array}{l}\text { estimated impact of the municipal council, } \\
\text { residents, environmental NGOs, investors, } \\
\text { other NGOs, municipal department of the } \\
\text { environment and spatial planning, the mayor, } \\
\text { RDA, MESP, sector ministries; questionnaire }\end{array}$ & $\begin{array}{l}0 \text { - very little impact } \\
1 \text { - low impact } \\
2 \text { - neither small nor big impact } \\
3 \text { - big impact } \\
4 \text { - very high impact }\end{array}$ \\
\hline $\begin{array}{l}\text { Frequency of participation with } \\
\text { different population groups }\end{array}$ & $\begin{array}{l}\text { frequency of participation was observed } \\
\text { for the neighbouring municipalities, RDA, } \\
\text { GORP, MESP, MPA, local NGOs, MAFF, MT, } \\
\text { ME, others; questionnaire }\end{array}$ & $\begin{array}{l}0 \text { - never } \\
1 \text { - rarely } \\
2 \text { - sometimes } \\
3 \text { - often }\end{array}$ \\
\hline $\begin{array}{l}\text { Quality of cooperation with } \\
\text { different population groups }\end{array}$ & $\begin{array}{l}\text { quality of cooperation was estimated for the } \\
\text { same group as the frequency, questionnaire }\end{array}$ & $\begin{array}{l}0 \text { - very bad } \\
1 \text { - poor } \\
2 \text { - neither bad nor good } \\
3 \text { - good } \\
4 \text { - very good }\end{array}$ \\
\hline $\begin{array}{l}\text { Evaluation of the level of public } \\
\text { participation on a five-point scale }\end{array}$ & $\begin{array}{l}\text { evaluation of public participation in spatial } \\
\text { planning, using the five-point scale by } \\
\text { the International Association for Public } \\
\text { Participation, questionnaire }\end{array}$ & $\begin{array}{l}\text { - } \text { information } \\
\text { - } \text { consultation } \\
\text { - integration } \\
\text { - } \text { cooperation } \\
\text { - } \text { transferring the decision-making } \\
\text { power to the public }\end{array}$ \\
\hline
\end{tabular}

ed municipalities we are operating with a representative sample. All units in the population had an equal opportunity to be selected, because we sent the questionnaire to all municipalities, but only about a quarter responded.

For the size difference between municipalities we prepared a typology that distinguishes municipalities by area, population size (data for the first half of 2009), population density and municipality type according to the OECD typology (urban/rural). This separates rural municipalities with population density below 150 inhabitants $/ \mathrm{km}^{2}$ - 44 municipalities - and urban municipalities with population density above 150 inhabitants $/ \mathrm{km}^{2}-11$ municipalities. Municipalities are sorted into two groups: the small, rural and less populated municipalities (38 municipalities), such as, for example, Škocjan, Cerknica, Zreče, Kuzma and Črenšovci, and the larger, urban and more densely populated municipalities (16 municipalities), such as Zagorje ob Savi, Slovenska Bistrica or Koper. Urban municipality Ljubljana was in its own, third group.

Questionnaires were filled in by representatives of municipalities responsible for spatial planning: heads of departments of the environment and spatial planning, advisors, directors of municipal administration and others. On average, they had held that position for eight years and have ten years experience in planning, mostly in the preparation and adoption of spatial plans. The questionnaire was completed by 20 women $(36.4 \%)$ and 35 men (63.6\%). The largest number of respondents had finished a university (31) or higher education (15), five had master's degrees, two had finished secondary school, two did not reply. By their field of studies they are mostly architects (13), followed by administrative organizers (5), geographers (4), and landscape architects (3), land surveyors (3) and civil engineers (3).

For collected data, in addition to basic descriptive statistics using multivariate clustering method by which a set of units are divided into groups by selected criteria (Bucik 2003), we created a typology of management capacity in the field of spatial planning. We chose hierarchical cluster analysis, which given the unknown number of groups produces a quick, simple and graphic result (Aldenderfer and Blashfield 1985). The selected rate for calculating the similarity is the squared Euclidean distance, which increases the difference between units, because at first glance the differences between the municipalities are not very big and it would otherwise be difficult to form exclusive groups. The selected algorithm to produce a matrix of similarity and grouping was Ward's algorithm as the most universal and applicable for measurable and categorical variables. In order to perform calculations in the statistical program, we filled the missing values with the average for that variable. The purpose of the typology was to determine how the municipalities could be classified according to their spatial management capacity and with that their implementation 


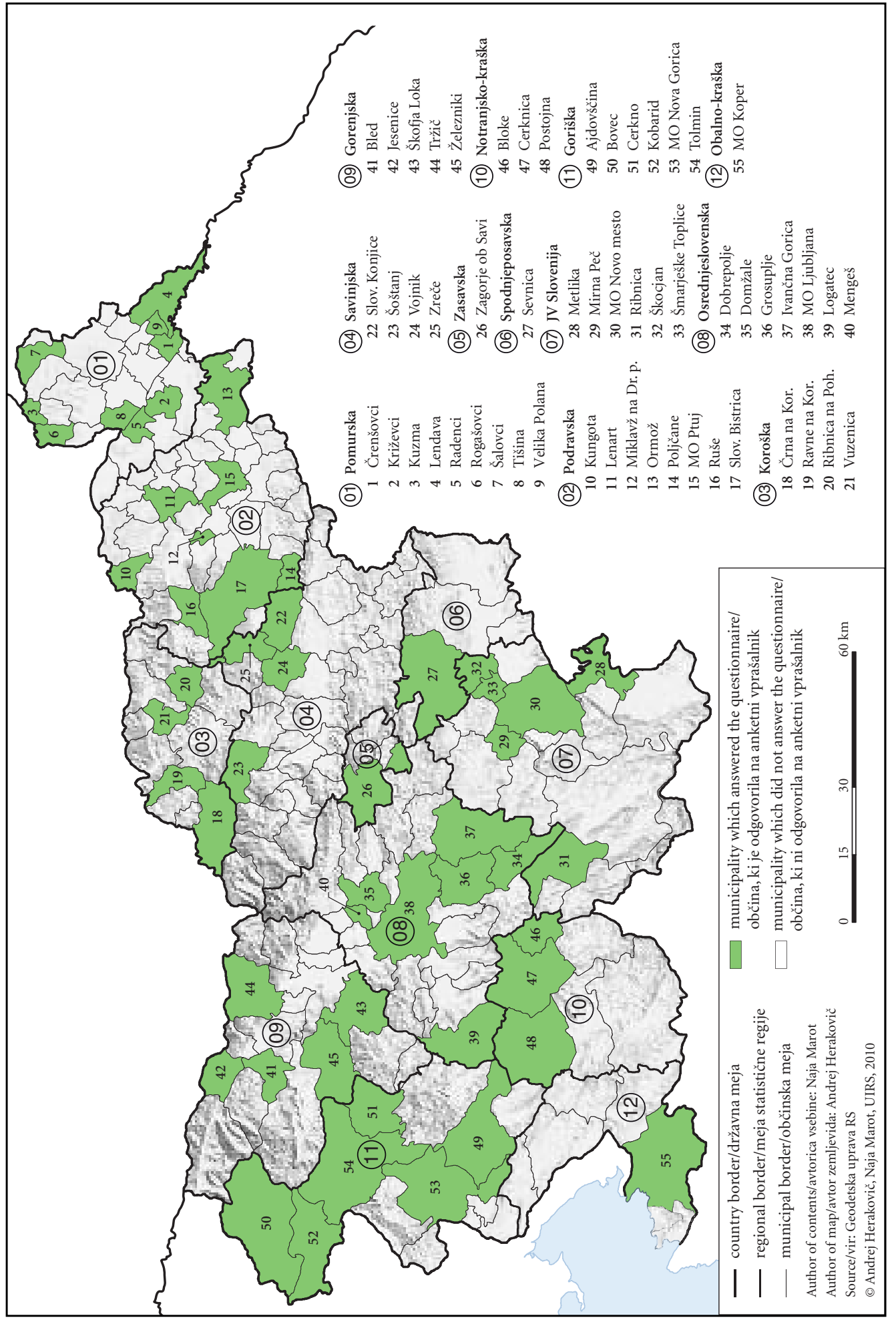


of spatial legislation. Such a classification of municipalities is a welcome piece of information for policy makers in the field of spatial planning and local self-government, as it helps optimize the functioning of public administration, thus contributing to the establishment of the desired spatial planning system, taking into account the realities, the current situation and needs. Additionally, we check whether there is a correlation between size and management typology of municipalities, so whether the claim that smaller municipalities have poor management capacity is true.

\section{Results by selected indicators}

The first indicator is meeting the legal population criterion for the establishment of municipalities, where we distinguished the basic and conditional criteria. Out of the responding municipalities 35 (63.6\%) were above the basic population minimum of 5,000, and additional 15 municipalities (27.3\%) met the conditional criterion of at least 2,000 people, so $91 \%$ of municipalities met at least one of the criteria for establishment. The public opinion is that fragmentation of municipalities, even if meeting at least the conditional criterion for establishment, reduces the capacity of municipal administrations to carry out their tasks (Blagajne and Šantej 2001; Ravbar and Bole 2002), so the respondents further assessed changes in quality of planning after the secession. There were 29 such municipalities in the sample; one did not assess the change. According to the assessments, the quality did not change in 14 municipalities, in four it declined, and ten municipalities reported an increase in management capacity. According to evaluations, secession does not necessarily affect the improvement of capacity, but the benefits of newly established, usually population- and surface area-wise smaller municipalities, as viewed by municipal planners, are in the reduction in size of the municipality and a better knowledge of the area, faster problem solving and implementation of development initiatives, in greater attention to spatial planning and the new jobs, equal inclusion of all settlements and in their own spatial planning documents. Municipalities with bad experience indicated poorer adequacy of the staff, as one person covers several fields and less thoroughly than before, and the exercise of individual interests of local leaders, where the municipal administration due to its small size cannot ensure comprehensive and high quality land management.

Staffing solutions for spatial planning are also related to the type of administration. Municipalities have either a unified municipal government without internal divisions to subunits or departments 32 municipalities (58\%), or the municipal administration is divided into departments - 23 municipalities $(42 \%)$. Despite a clear dividing line between the two types, the municipalities have very different organizational and staffing solutions in the field of spatial planning. The structure of administration is not permanent, as a municipality can dissolve a department with a new systematisation, forms a special office or spreads planning tasks among different departments. The diversity of solutions was analyzed with an overview of internal organization of the municipal administration in the field of spatial planning.

Thirty municipalities with unified administration have planning staff named according to their position and field. In addition to (senior) officer/assistant/advisor for the environment and spatial planning, the field is also covered by employees for economic infrastructure, management of building land, investment, planning and building land, social activities or they are consultants without designated fields. Within the municipality planning is also covered by the mayor, the municipal secretary, director of municipal administration, and outside the director of a public utility company and, in four cases, an outside municipal town planner - a spatial planning company, which illustrates the diversity of staffing solutions. Eighteen municipalities have a separate department for the environment and spatial planning, two municipalities have established a department for spatial planning and environment protection, and two established offices for spatial planning. Some municipalities have used the option of the Local Self-Government Act (ZLS-UPB2 2007) to set up a joint municipal administration to cover planning. In the group with joint municipal administrations there are Ormož (three municipalities), Ptuj (17 municipalities) and Lendava (three municipalities) who are also managers of respective joint municipal administrations, among other tasks responsible for at least municipal inspection wardens, and spatial planning.

The average rating of staff adequacy for planning is 3.4 - somewhere between partially adequate and adequate. Most municipalities chose adequate, namely 23, partially satisfied were 20 municipalities, while six municipalities (11\%) assessed their planning staffing solutions as inadequate. We were interested in the difference in the assessment of the adequacy of staffing in relation to the type of administration. Municipalities 


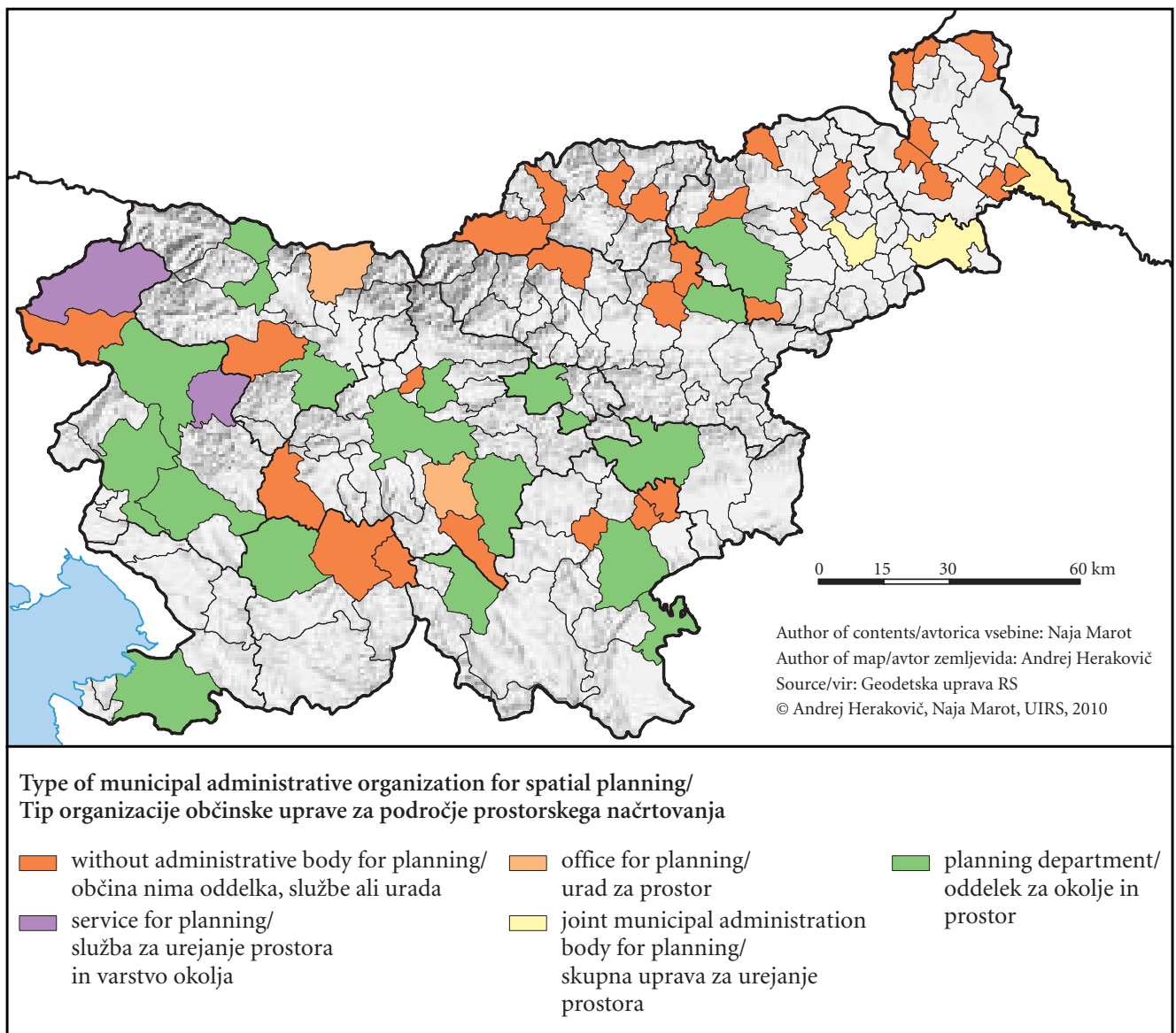

Figure 2: Municipalities by the type of municipal administrative organization for spatial planning.

with a unified administration are less satisfied with the staff adequacy for the purposes of planning, and 31 municipalities gave it the average mark of 3.2 - partly adequate (with both median and mode 3 ), while the 23 municipalities with divided administration were more satisfied with their staffing solutions, giving an average rating 3.7 - adequate (both median and mode 4 ). We see that type of administration affects the satisfaction with staffing solution.

The number of employees in spatial planning between municipalities varies greatly. Together the 55 municipalities employ 220.5 people; without the Municipality of Ljubljana and its 42 employees, the sum is 178.5 persons. On average, a municipality employs four people. Most municipalities - 19 - has one person employed, followed by ten municipalities with two planning staff. In municipal administrations with poorer human resources, one person covers several areas in addition to planning, while larger municipalities employ an average of 6 to 11 people.

Since the adoption of ZUreP-1 in 2003, 20 municipalities created new jobs, in two the number of jobs decreased. The new employees have different education and perform various tasks, such as operational building issues, traffic management, city planning and development, preparation of the MSP and others. Most municipalities with new jobs are population-wise mid- to large-sized, such as Jesenice, Zagorje ob Savi, Novo mesto, Postojna, Nova Gorica.

The need for new jobs was expressed by 32 municipalities, which together require 47 positions; 19 municipalities need one, six municipalities three, and four municipalities two posts. The calculation does not show a link between the type of administration/the current number of employees and the need for jobs, 


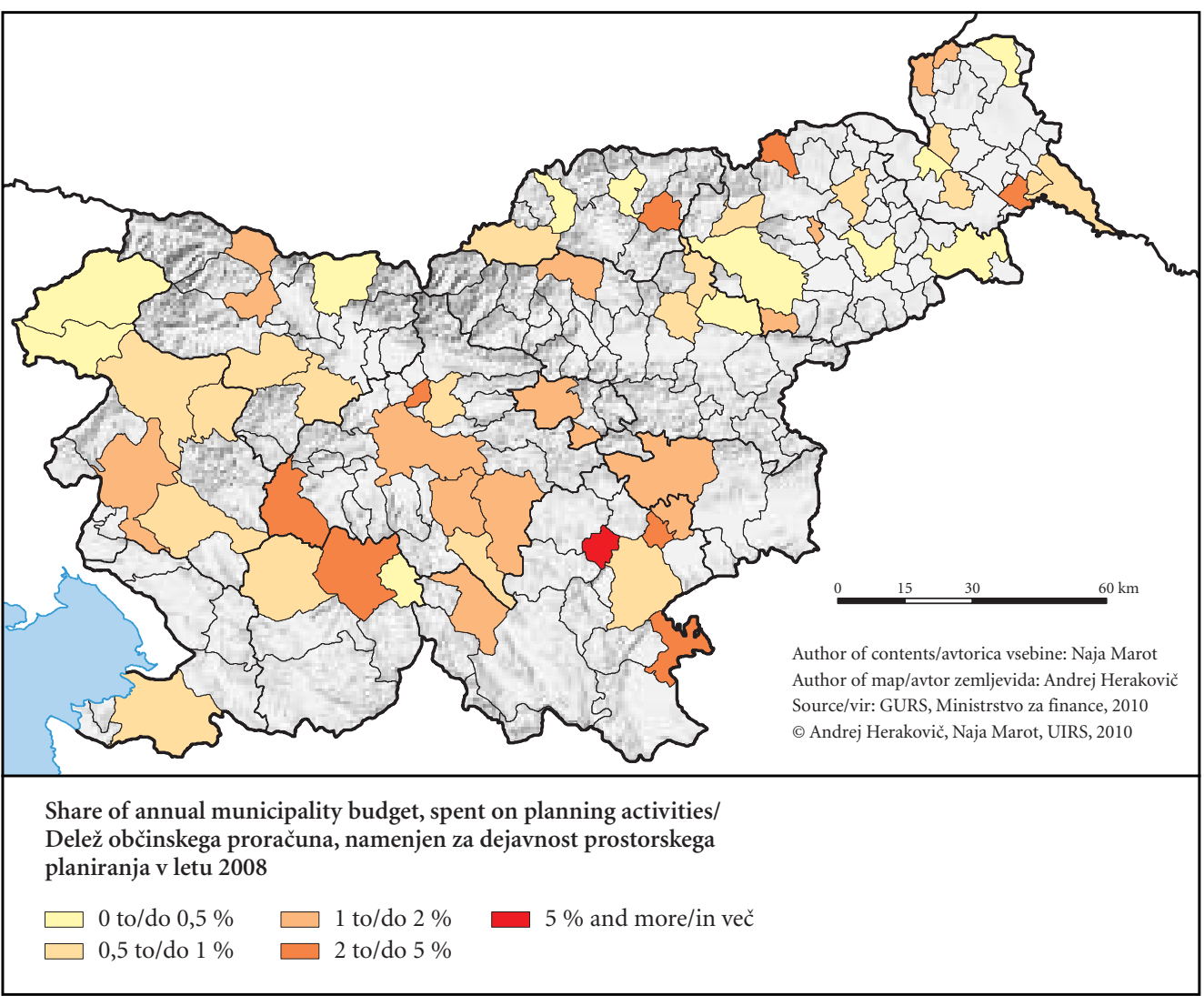

Figure 3: Share of annual municipality budget, spent on planning activities.

as new employees are needed in municipalities with a unified/divided administration and with smaller/larger staff. Education-wise the most popular choice would be an architect (8), followed by a landscape architect and representatives of other spatial disciplines and lawyers. Six municipalities regard skills and knowledge of new employees as more important than training: seven municipalities require their own municipal town planners, three GIS experts, other municipalities administrative support, a person to establish and maintain records, a specialist in planning law, assistance with the coordination between ministries and contracted producers, an the auditor for professional assessment of spatial plans and acts, and someone with the full understanding of space and development solutions. Some see the solution in the better education of existing rather than employing new people.

The data on the share of municipal budget funds for planning activities are available on the website of the Ministry of Finance (Ministrstvo za finance 2010). We chose the functional classification of spending, for which data are available for the years between 1999 and 2008. Comparability of data is ensured by calculating the proportion of the total municipal budget. To show the spending, we chose 1999 as the first year with available data, the year 2004 as the second year following the adoption of ZUreP-1 (2003) and 2008 as the year after the adoption ZPNačrt (2007). The average share of consumption per a municipality from the sample in 1999 was $2.44 \%, 2.31 \%$ in 2004 and $1.23 \%$ in 2008 , when the spending for spatial planning was reduced to only 24,448,557 Euros. Comparison with the total Slovenian average for the years 1999 and 2004 shows a below-average share for the sample, and in 2008 the shares were almost identical. Municipalities with the largest shares of municipal budget funds for planning in 2008 were: Mirna Peč (8.7\%), Ribnica na Pohorju (3.5\%), and Metlika (2.8\%), while Ptuj, Slovenske Konjice (0.1\%) and Šlovci with $0 \%$ were at the bottom. The values for 2008 were also used in the calculation of the typology. 
For the financial indicator a connection is assumed with the size of the municipality and consumption. The calculation of Pearson's coefficient shows no statistically significant relationship between the number of population and the municipal budget for spatial planning $(r=-0.017, p=0.901)$, and also between the surface and use $(r=-0.170, p=0.214)$ or type of administration and consumption $(\rho=-0.211, p=0.121)$.

Understanding spatial legislation also affects the planning management capacity. Fifteen representatives of the municipalities did not have any problems with understanding the ZPNacrrt, while the remaining 40 indicated at least one problem. The most commonly indicated was the unclear distribution of tasks (21), vague and complex text (20), the inconsistency of terms and duties (13) and the inadequacy of terms (9). The stylistic understanding of the text was the least problem, since municipalities are accustomed to legal texts in other fields. Under »other « municipalities highlighted the definition of certain terms, such as open space, scattered construction and scattered settlement.

Planning includes many stakeholders with different interests and impacts on the final spatial development, assessed by the municipality on a five-step interval scale and given a description of examples of stakeholders with large and very large impact. The thickness of the arrow in Figure 4 shows the numerically estimated size of the impact. The biggest impact on the content of spatial plans and land-development decisions of municipalities is that of sector ministries. Municipality described their impact are as negative, particularly in the case of the guidelines with which ministries as heads of planning guidelines determine whether MSP drafts and proposals are harmonized with national policies and, and provide suggestions for the consideration of initiatives in order to protect the space. The role of the guidelines in the preparation of the MSP is not understood the same by all the stakeholders, so the ministries take advantage of the power to shape local spatial policy with sector legislation rather than local communities.

MESP, the mayor, the investors, the municipal council and as the last in this group the department of the environment and spatial planning share about the same impact. MESP as the head of planning gives guidelines for the settlement, determines consistency of the MSP with national policies and decisions in the process of preparing the MSP. The mayor is the major catalyst of development at the municipal level, someone called them even chief designer and urbanist, as they make the final decision on spatial interventions, adopting spatial planning acts, areas of land development and the admissibility of construction proposals. In some municipalities they have positive experience with the mayor, as they understand the importance of space, provide appropriate staffing solutions, properly, constructively and responsibly take part in preparing the legislation and together with the planning department or the municipal council propose reasonable solutions. Due to dependence on voters they sometimes adopt solutions in conflict with

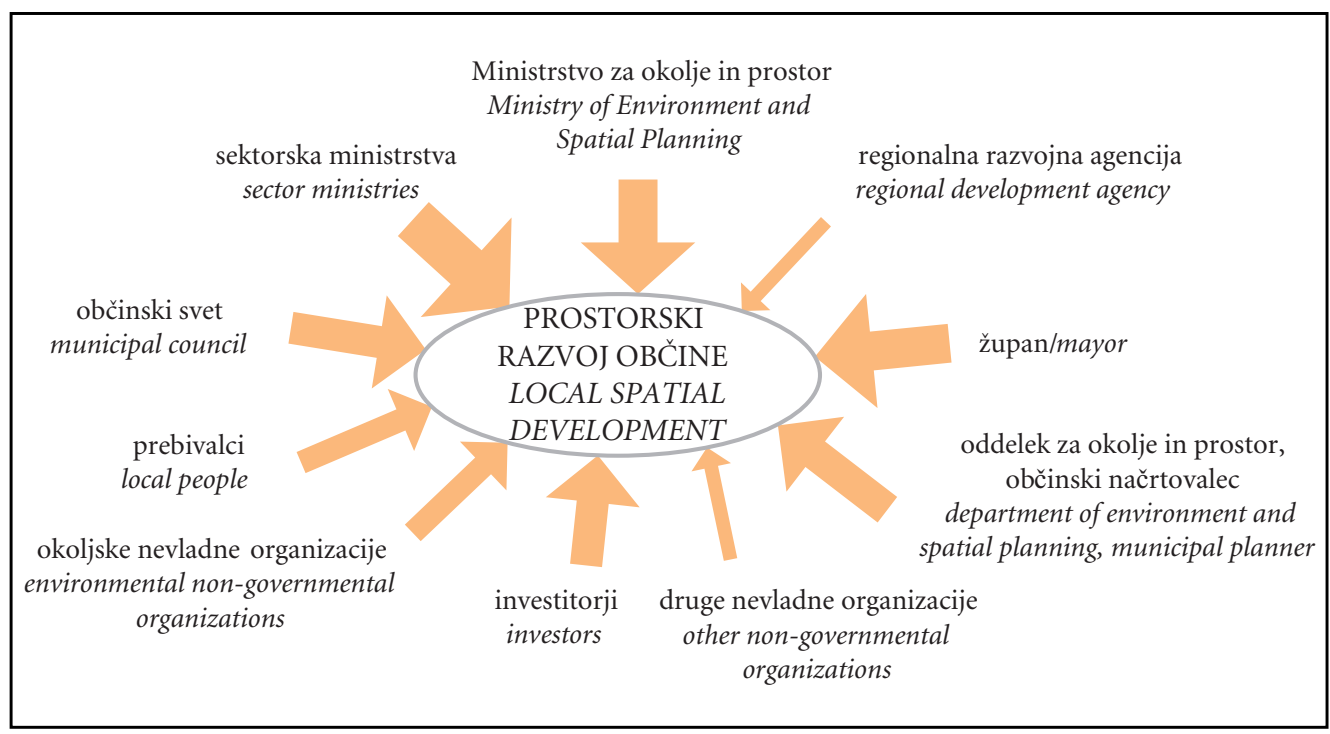

Figure 4: Size of the influence actors have on the spatial development in a municipality. 


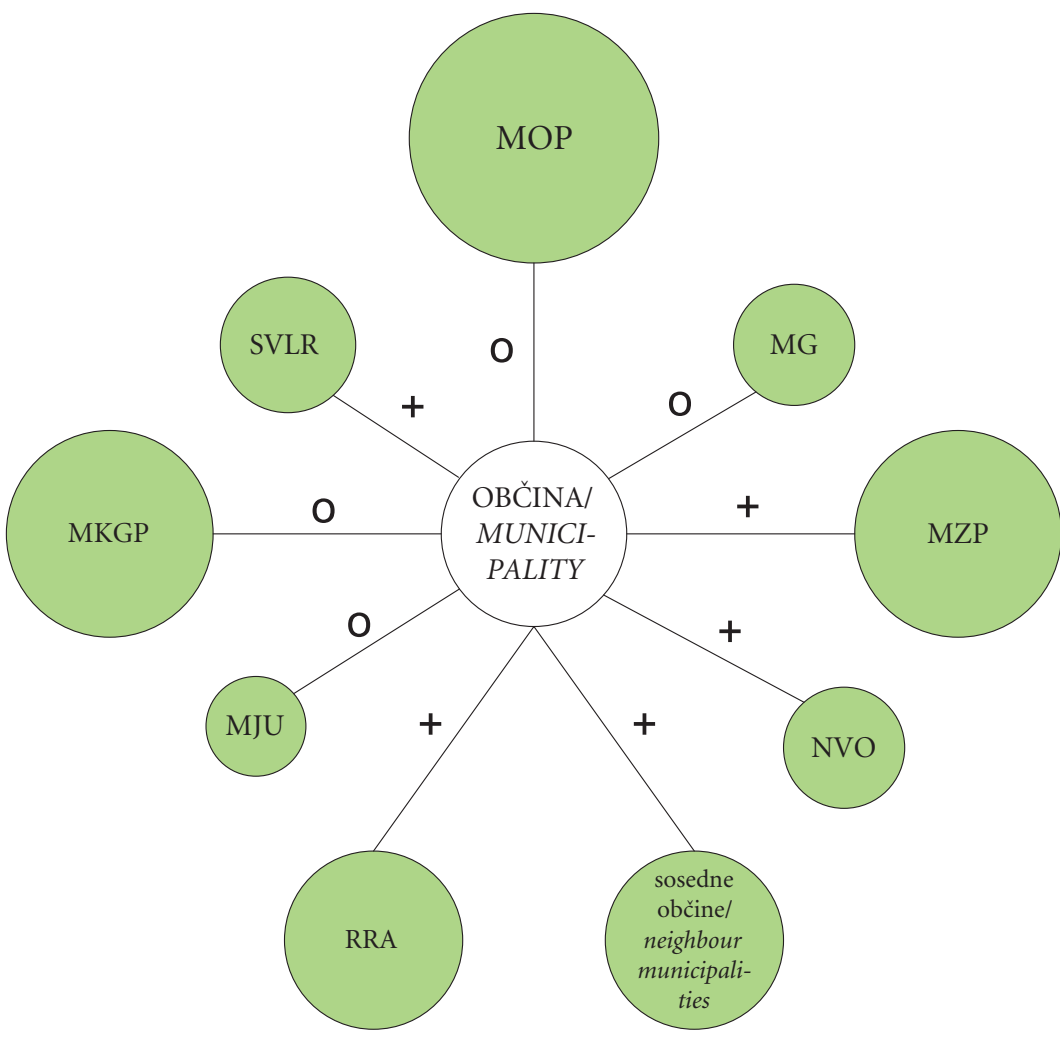

Figure 5: Scheme of frequency and quality of co-operation between the actors in the system of spatial planning when solving local spatial problems Pojasnilo kratic/Abbreviations: SVLR - Služba vlade RS za Iokalno samoupravo in regionalni razvoj/Government Office for Local Self-Government and Regional Policy, NVO - Nevladne organizacije/local non-governmental organizations, MJU - Ministrstvo za javno upravo/Ministry of Public Administration, MG - Ministrstvo za gospodarstvo/Ministry of the Economy, MKGP - Ministrstvo za kmetijstvo, gozdarstvo in prehrano/Ministry of Agriculture, Forestry and Food, MOP - Ministrstvo za okolje in prostor/Ministry of Environment and Spatial Planning, MZP - Ministrstvo za promet/Ministry of Transport, RRA - Regionalna razvojna agencija/regional development agency

Pojasnilo simbolov/Symbols: + kakovost sodelovanja je dobra/good co-operation, o - kakovost sodelovanja ni niti dobra niti slaba/moderate co-operation Velikost kroga pomeni pogostost sodelovanja, večji krog - pogosteǰse sodelovanje/Size of the circle indicates frequency of co-operation: bigger the circle, more frequent the co-operation

the expertise and the law, to cater to investors - the voters who put pressure on the mayor and leaders to support the implementation of their projects, such as construction of residential neighbourhoods.

Next to the mayor the municipal council is the highest municipal authority with executive power; by adopting acts and with amendments also it affects their final content, makes proposals for development, provides spatial objectives, often because of its political power also mischievously acts in accordance with its own interests and prevents the execution of certain projects. The municipal planning department leads the process of the preparation of spatial planning documents and as the only one with oversight of the actual situation in the area concerned ensure their quality and professionalism. In the process of document preparation it cooperates with outside contributors, residents and also provides project ideas, but does not have the decision-making power and can therefore only reach a compromise between expertise and policy with difficulty.

The impact of the local residents and environmental NGOs is neither small nor large. Residents are included in the spatial planning process at a public exhibition and hearing when they can attempt to influ- 
ence the development, but mainly in order to satisfy their own need to build on their own plot. In the case of organized approaches, such as those of environmental and other non-governmental organizations, they can more easily achieve their goal, although it is still difficult to determine whose interests they are really defending - the land, the discipline, public or individual interest have grown into public interest.

The frequency of cooperation between selected stakeholders is less than anticipated. With four of the nine stakeholders - the Government Office for Local Government and Regional Development, Ministry of Public Administration, local NGOs and ME - municipalities are on average only exceptionally involved in solving spatial problems. Municipalities sometimes consult the neighbouring municipalities, RDA, MAFF and the Ministry of Transport, but often cooperate with the MESP. In addition to stakeholders on the list, municipalities also highlighted other, local stakeholders: Institute for Nature Conservation, Institute for the Protection of Cultural Heritage, commercial public services and cross-border municipalities, are often involved. In addition to the frequency, the municipalities also assess the quality of cooperation. Most municipalities work well with all stakeholders, the highest ratings were given to neighbouring municipalities and the MT, followed by RDA, local NGOs and the Government Office for Local Government and Regional Development. The quality of cooperation with other stakeholders is neither good nor bad, the lowest rating was given to MAFF, on the border between very bad and poor quality of cooperation.

The degree of public participation was measured on a five-point scale of the International Association for Public Participation. As anticipated the participation level was very low, on average, municipalities use consultation, the public is informed of plans and invited to the written/oral transmission of the views and wishes in the context of public hearings, but later informed of the impact of contributions on the final decision (Umanotera poroča 2007). This was followed by the lowest level - the level of information, where the public is only informed of plans and projects of spatial development and given explanations of the problem and alternative solutions. Only six municipalities have opted for a more active public participation through workshops at the very beginning of the planning process or the establishment of partnership with the community. We additionally examined the relationship between the number of employees in the field of spatial planning and the degree of cooperation. The relationship is not statistically significant $(\rho=-0.193, p=0.183)$, so a large number of employees in the municipality does not necessarily guarantee a higher level of public participation.

\section{Municipality typology}

For selected indicators of management capacity, we were interested whether and how municipalities join into clusters. Using cluster analysis we separated them into three groups, namely - municipalities with poor conditions for the implementation of spatial planning regulations ( 37 municipalities), municipalities with fair conditions (17 municipalities) and the municipality of Ljubljana as the municipality with the best conditions. As anticipated in the group with poor conditions there were municipalities with a unified municipal administration, a smaller number of employees, municipalities established through secession, municipalities without a department of spatial planning or their own municipal town planner. They rate their staffing solutions for spatial planning as partially inadequate, on average they employ 1.6 persons in this field. Two-thirds of the municipalities with poor conditions require new staff. In the group with fair conditions all municipalities meet the basic legal criteria for establishment, four are urban. Most have divided administration with a department for the environment and spatial planning, or lead a unified administration and existed before the division into new municipalities. In addition to staffing solutions, what clearly separates the group are indicators: finance spending, level of participation in the planning process and stakeholders with impact on development. At average consumption of finances the result can be different than expected because better municipalities spent half as much money for spatial planning $-0.87 \%$ of municipal budget, but indicate they are more satisfied with their human resources. Frequency of interaction is also different between the groups. Most municipalities with fair conditions often cooperate with the Ministry of the Environment and Spatial Planning, and sometimes with the regional development agency, neighbouring municipalities, the Ministry of Transport and Ministry of Economy, while most of the "poor communities « are often only involved with the Ministry of Transport and RRD, sometimes with other stakeholders such as neighbouring municipalities, the Ministry of the Environment and Spatial Planning, Ministry of Agriculture, Forestry and Food. On average, the extent of participation 


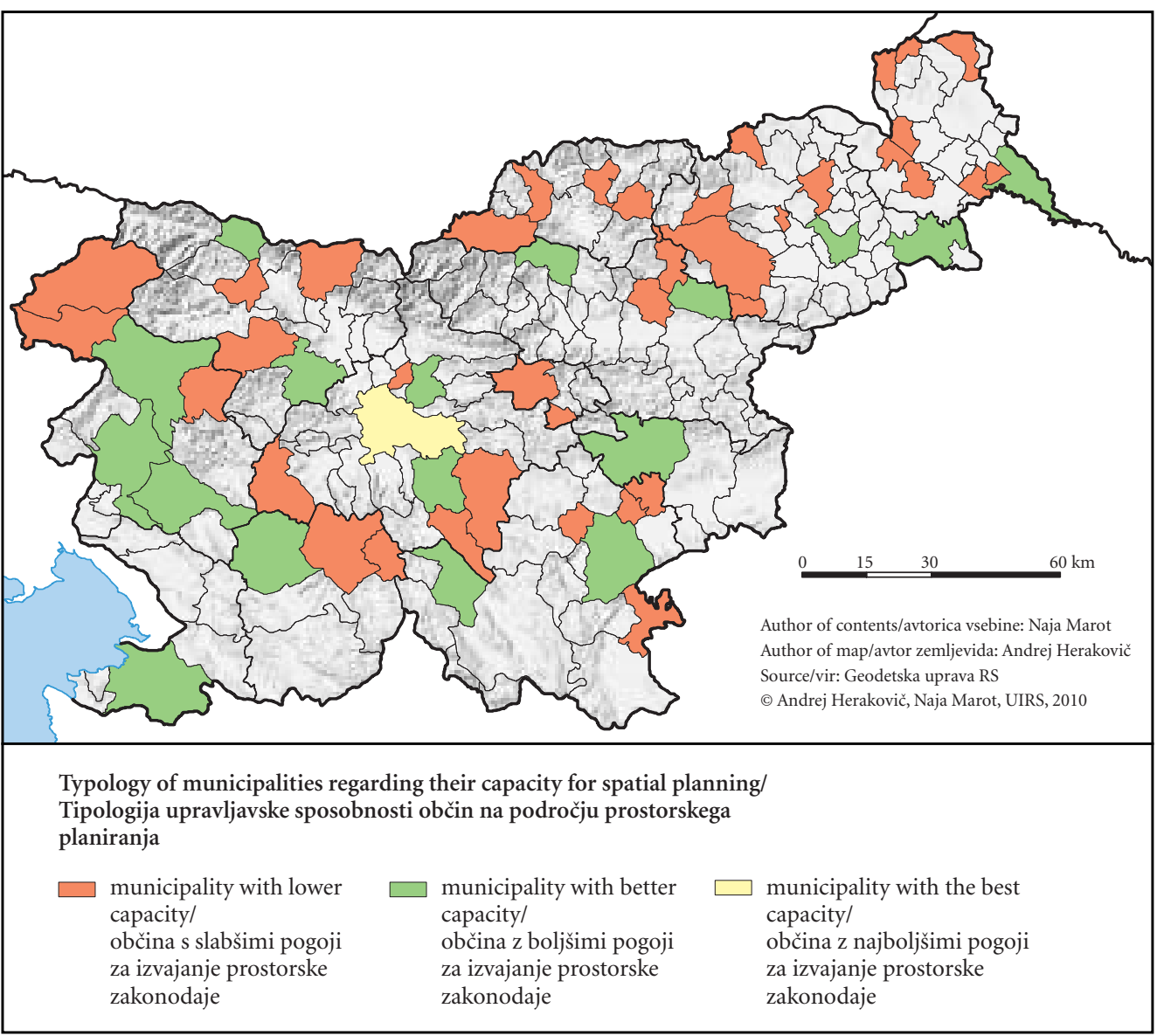

Figure 6: Municipalities by their territorial governance capacity.

of municipalities with poor conditions is narrower than that of municipalities with better conditions. The groups are also separated by impacts of individual stakeholders on the spatial development. Municipalities with poor conditions are most affected by the ministries, MESP, the mayor, department and the municipal council, while in municipalities with better conditions, environmental NGOs, residents and MESP have a small impact, others larger. In both groups, about one-fifth of the municipalities are without significant stakeholders' impact other than MESP with a large impact and the mayor, municipal council and investors with medium impact.

The other indicators: understanding the legislation, the need for new job posts, public participation and the quality of participation do not distinguish the groups clearly from one another and the result is different than expected. Thus, proportionally fewer (32\%) municipalities with poor social capital have more difficulty understanding the legislation than municipalities with better conditions (16\%). The estimated level of public participation is higher in "poor communities « where in some it reaches the level of integration and cooperation, whereas in most municipalities the public are included only in the context of consultation. The need for new jobs and quality collaboration are in both groups estimated similarly: municipalities from both groups need more staff, and for half cooperation with all stakeholders is good, except with the MPA, NGOs, MT and ME, with which it is average, and with the MAFF it is bad. One third of the municipalities cooperate well with everyone except the Ministry of Agriculture, Forestry and Food, Ministry of Public Administration, local NGOs and the Ministry of Economy. 


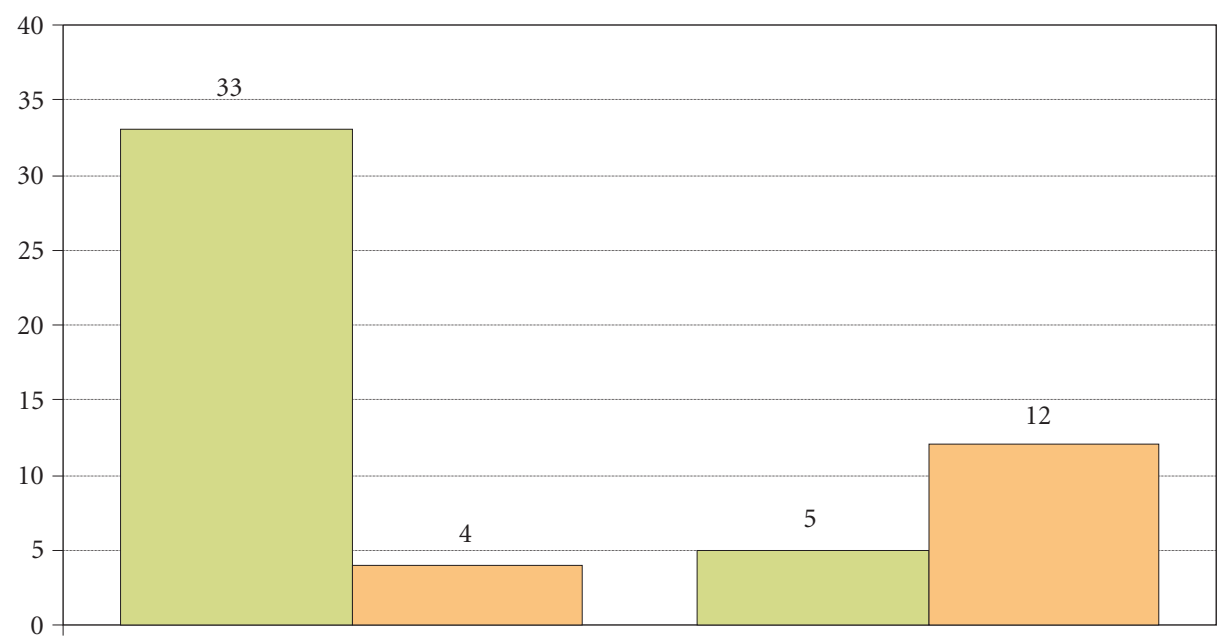

lower capacity/slabši pogoji

higher capacity/boljši pogoji

smaller, rural municipalities with low population density/

manjše, redkeje poseljene, pretežno ruralne občine

larger, urban municipalities with high population density/

večje, gosteje poseljene, pretežno mestne občine

Figure 7: Correlation between typology of capacity and typology of size.

The municipality of Ljubljana stands out with its divided administration and a special department of the environment and spatial planning with 42 employees with the annual consumption of $1.68 \%$ of municipal budget. Despite the assessment of employment conditions as adequate, however, they would still require additional staff. The public participates at the level of consultation, they collaborate with other stakeholders often and well, except with the ministries, with which other municipalities have problems, too. The biggest influences on the development of MOL are the municipal council, sector ministries, investors, the department and the mayor.

A comparison of governance and size typology - calculating $\chi^{2}$ with the value of 75.332 and $0 \%$ statistical risk - showed that the typologies are inter-dependent, and in municipalities of different "sizes «, we find a difference in governance capacity. The strong connection between the classification of municipalities in the management and size typology is further demonstrated by the calculation of Cramer's coefficient of 0.828 and a chart plotting of the frequency distribution.

\section{Conclusion}

The analysis showed that some municipalities have better conditions for the implementation of spatial legislation than others and therefore their capacity for planning is better. We demonstrated a link between the size of the municipality and the capacity to implement spatial legislation, but a more detailed analysis by individual indicators shows some unexpected differences, and therefore it is difficult to clearly divide the municipality to »bad and good.« For example, the average proportion of municipal budget resources is larger in municipalities with poorer conditions than in the better group. Indicators that distinguish municipalities well are staffing solutions of municipalities, finance consumption, frequency of participation with individual stakeholders and the power of influence of individual population groups on spatial develop- 
ment. From the analysis of cooperation we assume that the implementation of the legislation is easier if there is a large number of employees, a divided municipal administration, better and more frequent cooperation with all stakeholders, especially with the Ministry of the Environment and Spatial Planning, the utmost quality of cooperation and there are new job openings in this field. Despite some changes for the better the ability of municipalities still does not meet the demanding tasks of spatial planning legislation, which again illustrates the failure to take the situation into account during the preparation of new regulations. Poor collaboration between sector ministries shows to unregulated participation of national stakeholders in spatial planning. Although the law on the one hand requires municipalities to handle the implementation of activities in space rapidly and efficiently, ZPNacrt, as opposed to ZUreP-1, does not provide specific and mandatory staffing solutions, such as mandatory municipal town planner, large-scale public participation and does not clearly define the tasks of stakeholders.

The developed typology shows that the sample still contains more municipalities with poor conditions than those with better ones, so it is necessary to improve governance capacity. An improvement can be achieved in several ways. Given the low efficiency of the legal introduction of a municipal town planner who is employed only in a few municipalities, and the positive changes taking place in the system without legislative obligations, it makes sense to strengthen the capacity of municipalities with less severe measures. At a prerequisite that the importance of planning is recognized at the national policy level, we propose an intensive training of the current planning staff in more recent approaches to spatial planning and especially in its legal aspects, more staff, where the state must assist the financially poorer municipalities, a higher level of public participation and greater scope for cooperation among all stakeholders, because now some municipalities only rarely collaborate with others. This mode of planning is a part of all modern spatial planning types, such as participatory planning (Innes 1996), which move away from the binding formal procedures towards the establishment of discourse and the inclusion of several social groups to find suitable spatial solutions. More than the number of employees is the ability of planners, as their role is changing. They are no longer just plan producers, but more and more brokers (Kitchen 2006), who must know more than just the content of the spatial law. Informal solutions of system weaknesses and strengthening of management capacity was also proposed by the ESPON study (2006), after which it is necessary to improve vertical cooperation between national and local level, which also proved weak in our study. It was also confirmed that due to insufficient involvement of operators in the process of drafting the new regulation, the legislation did not provide adequate solutions for its implementation, as municipalities continue to lack sufficient conditions for the implementation, so they plan their space on different bases and in varying scopes. In addition to the discussed impact of governance capacity of municipalities on the quality of spatial planning, this is also influenced by factors not directly related to administration, such as the scope and content of spatial planners' skills or spatial culture and values of residents and stakeholders. These factors could be included in a comprehensive system analysis, while in this article focuses on the direct, legally regulated and conditioned governance aspect.

\section{References}

Aldenderfer, M. S., Blashfield, R. K. 1985: Cluster Analysis - Quantitative Applications in the Social Sciences. Newbury Park, London, New Delhi.

Black, J. 2002: Regulatory Conversations. Journal of Law and Society 29-1.Cardiff.

Blagajne, D., Šantej, B. 2001: Študija izvajanja prostorske zakonodaje o urejanju naselij, stavbnih zemljišč in graditve objektov. Elaborat, Inštitut za pravo okolja. Ljubljana.

Bucik, V. 2003: Razločevanje med »vodami življenja« ob pomoči analize razvrščanja v skupine. Panika 8-1/2. Ljubljana.

Cerar, M. 2006: Legitimnost prava. Kolumna IUS info. Internet: http://www.ius-software.si/Novice/ prikaz_clanek.asp?id=24366\&Skatla=17 (13.8.2009).

Cimolini, M., Knafič, I., Matjašec, D., Mlakar, A., Mohorič, R., Ostanek, P., Rozman, B. Č., Prijon, A. 2009: Anketa o delovanju ZAPS. Internet: www.arhiforum.si (19.10.2009).

Commission of the European Communities 2002: Communication from the commision on impact assessment COM 276. Brussels.

Council of European Communities 2001: White paper on European governance. COM 428. Brussels. 
Državni zbor Republike Slovenije 2002: Poslovnik Državnega zbora RS 2002. Ljubljana.

DUPPS - Društvo urbanistov in prostorskih planerjev Slovenije, Društvo krajinskih arhitektov Slovenije, Fakulteta za gradbeništvo in geodezijo Univerze v Ljubljani, Biotehniška fakulteta Univerze v Ljubljani, Zveza geodetov Slovenije, Urbanistični inštitut Republike Slovenije 2007. Skupno stališče o predlogu ZPN-ja za širšo javnost. Ljubljana.

ESPON 2006: ESPON project 2.3.2: Governance of Territorial and Urban Policies from EU to Local Level. Luxembourg.

Ferfila, B. 2008: Upravljavska sposobnost in koalicijsko povezovanje v slovenskih občinah. Ljubljana.

Fink-Hafner, D., Lajh, D. 2002: Analiza politik. Ljubljana.

Gerbec, F. 2003: (Z)mešani občutki in ocene. Pravna praksa 22-3/3-4. Ljubljana.

Golobič, M., Marušič, J. 2007: Developing an integrated approach for public participation: a case of land use planning in Slovenia. Environment and Planning B 34-6. Ljubljana.

Igličar, A. 2004: Sociologija prava. Ljubljana.

Innes, J. 1996: Planning through consensus building. Journal of American Planning Association 62-4. Chicago.

Jacobs, S. H. 2007: Current trends in the process and methods of regulatory impact assessment: maistreaming RIA into policy process. Regulatory Impact Assessment - Towards Better Regulation? Cheltenham.

Kitchen, T. 2006: Skills for Planning Practice. Houndmills, Basingstoke, Hampshire; New York.

Klančišar, K. 2006: Zasnova sonaravnega okoljskega razvoja Zasavja. Diplomska naloga. Ljubljana.

Klenovšek, U. 2003: Legitimnost prostorskega planiranja. Magistrsko delo. Ljubljana.

Kovač, P. 2005: RIA ali poprejšnja presoja vplivov predpisov - prispevek k sinergiji med javnim in zasebnim. Forum SFPO 2005 in EFQM - konferenca zmagovalcev. Ljubljana.

Majchrzak, A. 1987: Methods for Policy Research. Beverly Hills, London, New Delhi.

Marot, N. 2010: Presoja vloge prostorske zakonodaje v slovenskem sistemu prostorskega planiranja. Doktorska disertacija. Ljubljana.

Marot, N. 2011: New planning jurisdictions, scant resources and local public responsibility : delivering spatial planning in Slovenia. Territorial development cohesion and spatial planning. London; New York.

Martič, L. 2002: Delo in organizacija občinske uprave. Diplomska naloga. Ljubljana.

Ministrstvo za finance 2010: Podatki občin o realiziranih prihodkih in drugih prejemkih ter odhodkih in drugih izdatkih splošnega dela proračuna. Internet: http://www.mf.gov.si/slov/fin_loksk/obrazec_P_P1/ real_P_P1.htm (14.4.2010).

Ministrstvo za javno upravo 2005: Metodologija za izpolnjevanje in spremljanje Izjave o odpravi administrativnih ovir in sodelovanju zainteresirane javnosti. Začetna ocena učinkov predpisov. Internet: www.mju.gov.si/si/aktualno/metodologija_in_oao/ (14.4.2010).

Ministrstvo za okolje in prostor 2010: Pregled veljavnosti/uporabe členov Zakona o urejanju prostora (ZUreP-1) po uveljavitvi Zakona o prostorskem načrtovanju (ZPNačrt). Internet: http://www.mop.gov.si/ fileadmin/mop.gov.si/pageuploads/dokumenti/ostanek_zurep1.pdf (13.5.2010).

Mušič, V. B. 1978: Problematika občinskega sodelovanja na področju urejanja prostora v novih zakonih o urbanističnem in družbenem planiranju. Ljubljana.

OECD 2005: Guiding Principles for Regulatory Quality and Performance. Internet: http://www.oecd.org/ dataoecd/24/6/34976533.pdf (29.7.2009).

Pogačnik, A. 2007: Urejanje prostora po novem - Ali smo z novim zakonom dobili priložnost za bolj dinamičen in občanom prijaznejši razvoj v prostoru?. Urbani izziv 18-1/2. Ljubljana.

Poslovnik Vlade RS. Uradni list RS 43, 2001. Ljubljana.

Rakar, I. 2003. Pravni vidiki ocenjevanja predpisov 10. Ljubljana.

Ravbar, M., Bole, D. 2003: Sistem urejanja prostora. Ljubljana.

Resolucija o normativni dejavnosti (ReNDej). Uradni list RS 95, 2009. Ljubljana.

SURS 2010: Podatki o površini in številu prebivalcev. Internet: www.stat.si (14.3.2010).

Umanotera in Pravno-informacijski center za nevladne organizacije 2007. Ljubljana.

Zakon o lokalni samoupravi (ZLS-UPB2). Uradni list RS 94, 2007. Ljubljana.

Zakon o prostorskem načrtovanju (ZPNačrt). Uradni list RS 33, 2007. Ljubljana.

Zakon o urejanju prostora (ZUreP-1). Uradni list RS 110, 2002. Ljubljana.

Zavodnik Lamovšek, A. 2003: Prostorsko planiranje na poti k sistemski ureditvi. Urbani izziv 14-1. Ljubljana. 


\section{Upravljavska sposobnost slovenskih občin na področju prostorskega načrtovanja}

DOI: $10.3986 /$ AGS50106

UDK: 71:352(497.4)

COBISS: 1.01

IZVLEČEK: Ena izmed glavnih pristojnosti slovenskih občin je urejanje prostora, ki ga pravno urejamo z zakonom o prostorskem načrtovanju. Pogosto spreminjanje zakonodaje zahteva od občin prilagajanje v načinu upravljanja, uspešnost prilagajanja novim pogojem delovanja pa pogojuje uspešnost prostorskega razvoja. Z raziskavo smo ugotavljali, kakšni pogoji obstajajo v občinah za izvajanje prostorske zakonodaje, torej kakšna je upravljavska sposobnost občin za prostorsko načrtovanje. Opredelili smo trinajst kazalnikov, za katere smo podatke pridobili s pomočjo anketnega vprašalnika ali sekundarnih virov in jih na koncu povezali v tipologijo upravljavske sposobnosti. Ugotavljali smo, ali velikost občine in njene prostorske značilnosti vplivajo na razvrstitev po sposobnosti izvajanja. Petinpetdeset občin smo razvrstili v tri skupine: občine s slabšimi pogoji za izvajanje prostorske zakonodaje (37 občin), občine z boljšimi pogoji za izvajanje prostorske zakonodaje (17 občin) in Mestna občina Ljubljana kot občina z najboljšimi pogoji. Skupine se med seboj razlikujejo po kadrovskih rešitvah, porabi financ, pogostosti sodelovanja z deležniki in po njihovem vplivu. Primerjava med velikostno in upravljavsko tipologijo je pokazala njuno odvisnost, torej v različno velikih občinah najdemo različno sposobnost upravljanja. V sklepu so podani predlogi za izboljšanje upravljavske sposobnosti.

KLJUČNE BESEDE: geografija, prostorsko načrtovanje, občine, upravljanje, razvrščanje v skupine, Slovenija

Uredništvo je prejelo prispevek 24. maja 2010.

\section{NASLOV}

\section{dr. Naja Marot}

Urbanistični inštitut Republike Slovenije

Trnovski pristan 2, SI - 1127 Ljubljana, Slovenija

E-pošta: naja.marot@uirs.si

\section{Vsebina}

1 Uvod 149

2 Metode 150

3 Rezultati po izbranih kazalnikih $\quad 152$

4 Tipologija občin 155

5 Sklep 156

6 Literatura 157 


\section{Uvod}

Prostorsko načrtovanje je ena izmed glavnih pristojnosti slovenskih občin (ZLS-UPB2 2007). Občine kot lokalne skupnosti zagotavljajo kakovostno bivalno okolje, komunalno in prometno infrastrukturo, varujejo okolje, upravljajo z občinskim premoženjem, izvajajo zemljiško politiko in drugače skrbijo za prostor. Za nalogo prostorskega načrtovanja zato potrebujejo vsaj eno osebo. Po zakonu o urejanju prostora (ZUreP-1 2003) je bil to občinski urbanist, po zakonu o prostorskem načrtovanju (ZPNačrt 2007) ta $\mathrm{v}$ praksi ni več obvezen, čeprav preglednica o veljavnosti členov starega in novega zakona pravi drugače (MOP 2010). Novih rešitev, ki bi zagotovile večjo sposobnost upravljanja s prostorom, ZPNačrt (2007) ni prinesel, čeprav so razmere v sistemu urejanja prostora slabe (Gerbec 2003; Pogačnik 2007; Zavodnik Lamovšek 2003; Marot 2011 in drugi). Kadrovska zasedba je le eden od kazalnikov za oceno možnosti izvajanja prostorske zakonodaje, ki smo jo poimenovali tudi upravljavska sposobnost.

$\mathrm{V}$ članku zaradi pogoste rabe uporabljamo naslednje krajšave: $\mathrm{MG}$ - ministrstvo za gospodarstvo, MJU ministrstvo za javno upravo, MOP - ministrstvo za okolje in prostor, MKGP - ministrstvo za kmetijstvo, gozdarstvo in prehrano, MZP - ministrstvo za promet, $\mathrm{NVO}$ - nevladne organizacije, RRA - regionalna razvojna agencija, OECD - Organizacija za ekonomsko sodelovanje in razvoj, OPN - občinski prostorski načrt, SVLR - Služba Vlade RS za lokalno samoupravo in regionalni razvoj, DUPPS - Društvo urbanistov in prostorskih planerjev Slovenije, SURS - Statistični urad Republike Slovenije.

$\mathrm{Z}$ upravljavsko sposobnostjo se načrtovalci ali pripravljavci predpisov največkrat soočijo v postopku priprave prostorske zakonodaje, podzakonskega akta ali med njegovim izvajanjem, ko naletijo na določene ovire in se pričakovani cilji dosegajo počasneje od predvidenega. V slovenskem prostoru zasledimo večje število zapisov o problematiki izvajanja prostorske zakonodaje in analizi stanja, na primer že Mušič (1978) omenja primerjalno študijo tuje in domače prostorske zakonodaje, ki naj bi pomagala pri pripravi naslednje prostorske zakonodaje iz leta 1984. V 90. letih je ministrstvo za okolje in prostor izvedlo obsežno anketiranje, vendar podatki niso bili obdelani za potrebe ocene dejavnosti urejanja prostora. Najnovejši obsežnejši študiji so izvedli Blagajne in Šantej (2001) ter Ravbar in Bole (2002). Prva dva sta v okviru Inštituta za pravo okolja s pomočjo vprašalnika, izvedenega v občinah in upravnih enotah, pridobila informacije o kapaciteti, postopku sprejemanja aktov, občinskih problemih urejanja prostora in možnih rešitvah ter predlogih za izvajalca. Ravbar in Bole (2002) sta se bolj posvetila sistemski ureditvi prostora. Širše zasnovano raziskavo o kadrovsko-organizacijskih vidikih, medobčinskem sodelovanju in uvajanju podjetniških načel v delovanje občinske uprave so na vzorcu 118 občin izvedli na Fakulteti za družbene vede (Ferfila 2008). Ugotovitve vseh raziskav so podobne - večina občin ima enovito upravo, občine so kadrovsko šibke in potrebujejo dodatne kadre, finančni viri za prostorsko načrtovanje se zmanjšujejo (Ravbar in Bole 2002; Marot 2010), sodelovanje javnosti je omejeno (Golobič in Marušič 2007). V letu 2009 je Zbornica za arhitekturo in prostor pripravila krajši vprašalnik, po katerem $60 \%$ anketiranih spremembe zakonodaje in neurejene razmere $\mathrm{v}$ prostorskem načrtovanju ovirajo pri delu (Cimolini in ostali 2009).

Izvedene raziskave so pokrile določene vidike upravljanja s prostorom, vendar so bili njihovi sklepi le omejeno vključeni v proces priprave nove zakonodaje. Postopek priprave, vključenost izvajalcev vanj in ocenjevanje učinkov zakonodaje urejata Poslovnik Vlade RS (2001) in Poslovnik Državnega zbora RS (2002) Po poslovniku vlade se ocenjujejo finančne posledice osnutka akta in pripravijo drugi podatki in informacije, potrebne za odločanje, mnenja podajo vsa pristojna ministrstva in službe vlade. Na podlagi presoje učinkov predpisov, s katero je v osemdesetih letih 20. stoletja začel OECD in jo je leta $2001 \mathrm{v}$ Beli knjigi o upravljanju (2001) uvedla tudi Evropska unija, so se v Sloveniji podobno kot v večini drugih evropskih držav odločili za okrnjeno različico presoje in jo poimenovali začetna ocena učinkov predpisov. Ocena predpisa daje poudarek zmanjšanju birokratskih ovir pri nastanku in poslovanju podjetij, večji preglednosti pogojev poslovanja ter transparentnosti delovanja javne uprave in porabe sredstev (Metodologija 2005). Čeprav je poudarjeno sodelovanje javnosti, mnenje posameznikov največkrat ne vpliva dosti na končni predpis. To se je pokazalo pri pripravi najnovejše prostorske zakonodaje, kjer organizirana javnost kljub usklajenosti ni mogla preprečiti sprejema neustreznega predpisa (DUPPS in ostali 2007). Glavna metoda zbiranja informacij je vprašalnik, vendar ni namenjen izdelavi širše, tudi vsebinske presoje stanja upravljanja področja. Najnovejši okvir za presojo okolja za izvajanje zakonodaje je Resolucija o normativni dejavnosti (2009). Potrebno raven upravljavske sposobnosti naj bi zagotovili s predhodnimi poglobljenimi analizami problemov, jasno določenimi cilji, oceno upravičenosti in primernosti predpisovanja ter možnostmi poenostavitve. Kljub ustreznemu, načelno vzpostavljenemu sistemu priprave 
predpisov, ki zahteva predhodne ocene, je praksa drugačna, kar kaže primer zadnje prostorske zakonodaje-ZPNačrt (2007). V raziskavi o postopku priprave zakonodaje sta Pravno-informacijski center nevladnih organizacij in Umanotera (2007) ugotovila, da so pripravljavci sicer zagotovili vključevanje zainteresirane javnosti v najzgodnejše faze priprave prostorske zakonodaje in predstavili različne rešitve vsebine, a niso naročili strokovnih podlag za oceno dejanskega stanja sistema, v katerem se bo nova zakonodaja izvajala, in niso dali povratne informacije o upoštevanju predlogov.

Manjši poudarek na vključevanju izvajalcev v pripravo predpisov je v nasprotju z dognanji Blacka (2002), ki pravi, da učinkovitost predpisa ni odvisna od moči regulatorja, ampak od odnosa zakonodajalca do izvajalca zakonodaje in obratno. Če želi zakonodajalec zagotoviti uspešno izvajanje, mora upoštevati stanje sistema - način delovanja in vrednote deležnikov, širše institucionalno okolje, različno logiko delovanja regulativnih orodij in strategij - ter spremembe katerega koli dela sistema (Igličar 2004). Na osnovi stanja sistema, določil zakonodajnega postopka in dosedanje prakse smo z analizo stanja ugotavljali, kakšna je upravljavska sposobnost za urejanje prostora. Presoja izvedljivosti je le en del sicer širše zasnovane raziskave, namenjene celostni presoji prostorske zakonodaje (Marot 2010).

\section{Metode}

Pri zasnovi metode smo izhajali iz različnih presojevalskih metod, da bi zasnovali analizo, ki bo ustrezno vključila njene izvajalce. Naslonili smo se na metodo presoje učinkov predpisov (regulatory impact assessment), ki predstavlja »mednarodno uveljavljeno analitično in komunikacijsko orodje, ki ga $v$ zadnjih dveh desetletjih po vsem svetu uporabljajo v javni upravi s cilji odprave nepotrebne regulative ter izboljšanja kakovosti in izvajanja predpisov « (Kovač 2005; Rakar 2003; OECD 2005). Dodatno smo črpali še iz presoje družbenih učinkov ( social impact assessment), ki meri učinke izbrane politike/predpisa na upravljanje, dobro administracijo in udeležbo javnosti (Majchrzak 1987). Širše zastavljena metoda presoje vsebuje šest kriterijev (razumljivost, izvedljivost, učinkovitost, sprejemljivost, odprtost in transparentnost, trajnost; za opredelitev kriterijev dobre zakonodaje so bili uporabljeni naslednji viri: Cerar 2006; CEC 2001; CEC 2002; Fink-Hafner in Lajh 2002, Jacobs v Kirkpatrick in Parker 2007; Klančišar 2006; Klenovšek 2003; Ministrstvo za javno upravo 2005; OECD 2005), podrobneje ovrednotenih s pomočjo kazalnikov, v tem članku pa združujemo ugotovitve po posameznih, izbranih kazalnikih v pregledno tipologijo upravljavske sposobnosti. Izbrali smo trinajst kazalnikov upravljavske sposobnosti (glej preglednico 1), s katerimi merimo ustreznost kriterija za nastanek občine in nastanek občine $\mathrm{z}$ odcepitvijo, ustreznost kadrovskih rešitev in potrebe po zaposlenih, razpoložljive finance, težave $\mathrm{z}$ razumevanjem zakonodaje, ki vplivajo na izvedbo, raven sodelovanja javnosti ter vpliv, pogostost in kakovost sodelovanje različnih skupin prebivalstva.

Preglednica 1: Kazalniki, uporabljeni za merjenje upravljavske sposobnosti.

\begin{tabular}{|c|c|c|}
\hline kazalnik & opis kazalnika, vir podatkov & način merjenja/kategorije \\
\hline nastanek občine z odcepitvijo & $\begin{array}{l}\text { Občina je nastala z odcepitvijo po letu } 1993 \text { - } \\
\text { potencialna sprememba upravljavske } \\
\text { sposobnosti za prostor; Statistični urad RS, } \\
\text { podatki o teritorialni ureditvi. }\end{array}$ & $\mathrm{da} / \mathrm{ne}$ \\
\hline $\begin{array}{l}\text { ustreznost zakonskemu kriteriju } \\
\text { za nastanek občine glede } \\
\text { minimalnega števila prebivalcev }\end{array}$ & $\begin{array}{l}\text { Občina (ne)ustreza zakonskemu kriteriju; } \\
\text { Statistični urad RS, podatki o številu prebivalcev } \\
\text { ob ustanovitvi. }\end{array}$ & $\begin{array}{l}\text { - } \text { nad osnovno mejo } 5.000 \text { preb. } \\
\text { - med pogojno } 2.000 \text { preb. in osnovno } \\
\text { mejo } 5.000 \text { preb. } \\
\text { - pod pogojno mejo } 2.000 \text { preb. }\end{array}$ \\
\hline tip uprave & $\begin{array}{l}\text { Tip uprave, prisoten v posamezni občini; } \\
\text { Služba Vlade RS za lokalno samoupravo } \\
\text { in regionalni razvoj, dodatno telefonski intervju, } \\
\text { Martič (2002). }\end{array}$ & $\begin{array}{l}\text { - enovita uprava (brez notranje razdelitve) } \\
\text { - razdeljena uprava }\end{array}$ \\
\hline $\begin{array}{l}\text { notranja organizacija občinske } \\
\text { uprave za področje prostorskega } \\
\text { načrtovanja }\end{array}$ & $\begin{array}{l}\text { Organizacijska ureditev znotraj občinske uprave } \\
\text { za področje urejanja prostora; anketni vprašalnik. }\end{array}$ & $\begin{array}{l}\text { - } \text { brez oddelka za okolje in prostor } \\
\text { - } \text { oddelek za okolje in prostor } \\
\text { - } \text { služba za urejanje prostora in varstvo okolja } \\
\text { - } \text { urad za prostor } \\
\text { - } \text { skupna uprava za urejanje prostora }\end{array}$ \\
\hline
\end{tabular}




\begin{tabular}{|c|c|c|}
\hline lasten občinski urbanist & $\begin{array}{l}\text { Obstoj osebe, ki pokriva urejanje prostora po } \\
\text { opredelitvi ZUreP-1 (2003); anketni vprašalnik. }\end{array}$ & $\mathrm{da} / \mathrm{ne}$ \\
\hline $\begin{array}{l}\text { delež sredstev občinskega } \\
\text { proračuna za prostorsko } \\
\text { načrtovanje }\end{array}$ & $\begin{array}{l}\text { Delež porabe sredstev občinskega proračuna } \\
\text { v celotnem proračunu, za prostorsko načrtovanje; } \\
\text { postavka } 062 \text { po klasifikaciji COFOG za leto 2008; } \\
\text { ministrstvo za finance, lastni preračun (COFOG - } \\
\text { Classification of the Functions of Government. } \\
\text { Kategorija porabe občin »stanovanjska dejavnost } \\
\text { in storitve lokalne skupnosti « ima podkategorijo } \\
\text { dejavnost prostorskega načrtovanja, ki vključuje } \\
\text { upravljanje prostorskega razvoja lokalne skupnosti, } \\
\text { izvajanje zakonodaje in predpisov s področja } \\
\text { prostorskega načrtovanja in gradnje, načrtovanje } \\
\text { novih sosesk ali prenove starih in drugo; } \\
\text { Ministrstvo za finance 2010). }\end{array}$ & vrednost v \% \\
\hline težave z razumevanjem Zpnačrt & $\begin{array}{l}\text { Obstoj težav prostorskih načrtovalcev pri } \\
\text { razumevanju zakonodaje; anketni vprašalnik. }\end{array}$ & $\begin{array}{l}\text { a) Z razumevanjem določil in besedila } \\
\text { zakonodaje ni bilo težav. } \\
\text { b) Besedilo zakona je nejasno in zapleteno } \\
\text { (vsebinsko razumevanje). } \\
\text { c) Besedilo zakona je težko berljivo (slogovno } \\
\text { razumevanje). } \\
\text { č) Določila in naloge občine v zakonu niso } \\
\text { dosledno (enolično) določeni. } \\
\text { d) Razdelitev nalog med različnimi upravnimi } \\
\text { ravnmi uprave ni jasna. } \\
\text { e) Izrazi, uporabljeni za posamezne pojme } \\
\text { oziroma prostorske pojave, niso ustrezni. } \\
\text { (Možnih je več odgovorov.) }\end{array}$ \\
\hline $\begin{array}{l}\text { ocena kadrovske ustreznosti za } \\
\text { urejanje prostora s strani občine }\end{array}$ & $\begin{array}{l}\text { Številčna ocena kadrovske ustreznosti } \\
\text { za urejanje prostora; anketni vprašalnik. }\end{array}$ & $\begin{array}{l}\text { 1- popolnoma neustrezen } \\
2 \text { - neustrezen } \\
3 \text { - delno ustrezen } \\
4 \text { - ustrezen } \\
5 \text { - zelo ustrezen }\end{array}$ \\
\hline $\begin{array}{l}\text { število zaposlenih na občini } \\
\text { za urejanje prostora }\end{array}$ & $\begin{array}{l}\text { Število zaposlenih, ki se ukvarjajo z dejavnostjo } \\
\text { urejanja prostora; anketni vprašalnik. }\end{array}$ & absolutno število \\
\hline potreba po novih delovnih mestih & $\begin{array}{l}\text { Obstoj potrebe po novih delovnih mestih } \\
\text { na področju urejanja prostora, dodatno } \\
\text { podan tudi opis; anketni vprašalnik. }\end{array}$ & $\mathrm{da} / \mathrm{ne}$ \\
\hline $\begin{array}{l}\text { vpliv posameznih skupin } \\
\text { prebivalstva na prostorski razvoj }\end{array}$ & $\begin{array}{l}\text { Vpliv ocenjen za občinski svet, prebivalce, } \\
\text { okoljske NVO, investitorje, druge NVO, občinski } \\
\text { oddelek za okolje in prostor, župana, RRA, MOP, } \\
\text { sektorska ministrstva; anketni vprašalnik. }\end{array}$ & $\begin{array}{l}0 \text { - zelo majhen vpliv } \\
1 \text { - majhen vpliv } \\
2 \text { - niti majhen niti velik vpliv } \\
3 \text { - velik vpliv } \\
4 \text { - zelo velik vpliv }\end{array}$ \\
\hline $\begin{array}{l}\text { pogostost sodelovanja } \\
\text { s posameznimi skupinami } \\
\text { prebivalstva }\end{array}$ & $\begin{array}{l}\text { Pogostost sodelovanja je bila ugotovljena } \\
\text { za sosednje občine, regionalna razvojna agencija, } \\
\text { Služba Vlade RS za lokalno samoupravo } \\
\text { in regionalni razvoj, MOP, MJU, lokalne NVO, } \\
\text { MKGP, ministrstvo za promet, MG, drugo; } \\
\text { anketni vprašalnik. }\end{array}$ & $\begin{array}{l}0 \text { - nikoli } \\
1 \text { - izjemoma } \\
2 \text { - včasih } \\
3 \text { - pogosto }\end{array}$ \\
\hline $\begin{array}{l}\text { kakovost sodelovanja } \\
\text { s posameznimi skupinami } \\
\text { prebivalstva }\end{array}$ & $\begin{array}{l}\text { Kakovost sodelovanja je bila ocenjena za iste } \\
\text { skupine kot pogostost; anketni vprašalnik. }\end{array}$ & $\begin{array}{l}0 \text { - zelo slabo } \\
1 \text { - slabo } \\
2 \text { - niti slabo niti dobro } \\
3 \text { - dobro } \\
4 \text { - zelo dobro }\end{array}$ \\
\hline $\begin{array}{l}\text { ocenjena raven sodelovanja } \\
\text { javnosti na petstopenjski lestvici }\end{array}$ & $\begin{array}{l}\text { Ocena vključevanja javnosti v postopke } \\
\text { prostorskega načrtovanja, uporabljena } \\
\text { petstopenjska lestvica mednarodne zveze } \\
\text { za sodelovanje javnosti; anketni vprašalnik. }\end{array}$ & $\begin{array}{l}\text { - informiranje } \\
\text { - posvetovanje } \\
\text { - vključevanje } \\
\text { - sodelovanje } \\
\text { - prenos odločevalske moči na javnost }\end{array}$ \\
\hline
\end{tabular}


Na anketni vprašalnik je odgovorilo 55 občin od 210, skupaj $26 \%$, ki pokrivajo $6.946 \mathrm{~km}^{2}-34 \%$ slovenskega ozemlja in v njih po podatkih 30.6. 2009 živi 891.676 ljudi, kar je $44 \%$ prebivalstva. Najmanjša občina je Miklavž na Dravskem polju z 12,5 km², največja pa Tolmin s $381,50 \mathrm{~km}^{2}$. Prebivalstveno najmanjša je Ribnica na Pohorju s 1.246 prebivalci, največja Mestna občina Ljubljana z 278.314 prebivalci (SURS 2010). Največ občin je iz pomurske (9), podravske (8) in osrednjeslovenske regije (7). Primerjava vzorca s populacijo - z vsemi slovenskimi občinami - je pokazala, da po tipu občin in uprave vzorec ustreza populaciji, razlike so $\mathrm{v}$ površini, razporeditvi po prebivalstvenih kategorijah in doseganju zakonske meje, kjer je v vzorcu manjši delež občin pod zakonsko mejo kot v populaciji. Tako lahko zaključimo, da $\mathrm{v}$ primeru 55 izbranih občin operiramo z reprezentativnim vzorcem. Vse enote v populaciji so imele enakovredno možnost biti izbrane, saj smo anketni vprašalnik poslali vsem občinam, odzvala se jih je približno ena četrtina.

Slika 1: Občine, ki so odgovorile na vprašalnik, in njihova zastopanost po regijah.

Glej angleški del prispevka.

Za velikostno razlikovanje med občinami smo izdelali tipologijo, ki razlikuje občine po površini, številu prebivalcev (podatek za prvo polovico leta 2009), gostoti poselitve in uvrščenosti občine v tipologijo OECD glede na mestnost/ruralnost občine. Ta ločuje ruralne občine z gostoto, manjšo od $150 \mathrm{preb} . / \mathrm{km}^{2}-$ 44 občin, in mestne z gostoto, večjo od 150 preb. $/ \mathrm{km}^{2}-11$ občin. Občine so se razvrstile v dve skupini: $\mathrm{v}$ manjše, ruralne in redkeje poseljene občine (38 občin), kamor na primer uvrščamo Škocjan, Cerknico, Zreče, Kuzmo in Črenšovce, in v večje, mestne in gosteje poseljene občine (16 občin), kot so Zagorje ob Savi, Slovenska Bistrica in Mestna občina Koper. Mestna občina Ljubljana se je izločila kot svoja, tretja skupina.

Na vprašalnik so odgovarjali predstavniki občin, zadolženi za prostorsko načrtovanje: vodje oddelkov za okolje in prostor, svetovalci, direktorji občinske uprave in drugi. Povprečno so na delovnem mestu osem let in imajo deset let izkušenj v prostorskem načrtovanju, največ s pripravo in sprejemanjem prostorskih aktov. Anketni vprašalnik je izpolnilo 20 žensk (36,4\%) in 35 moških (63,6\%). Največje število anketirancev ima univerzitetno (31), višjo ali visokošolsko izobrazbo (15), pet je magistrov, dva sta končala srednjo šolo, dva nista odgovorila. Po smeri prevladujejo arhitekti (13), sledijo upravni organizatorji (5), geografi (4) ter krajinski arhitekti(3), geodeti (3) in gradbeniki (3).

Za pridobljene podatke smo poleg osnovne opisne statistike z multivariatno metodo razvrščanja v skupine, s katero množico enot po izbranih kriterijih razvrstimo v skupine (Bucik 2003), izdelali tipologijo upravljavske sposobnosti za področje urejanja prostora. Izbrali smo hierarhično razvrščanje v skupine, saj pri nepoznanem številu skupin poda hiter, preprost in nazoren rezultat (Aldenderfer in Blashfield 1985). Izbrana mera za računanje podobnosti je kvadrirana evklidska razdalja, ki poveča razlike med enotami, saj na prvi pogled razlike med občinami niso tako velike in drugače težko dobimo ekskluzivne skupine. Izbrani algoritem za izdelavo matrike podobnosti in združevanje v skupine je Wardov algoritem kot najbolj univerzalen in uporaben na merljivih in kategoričnih spremenljivkah. Za potrebe izračuna v statističnem programu smo manjkajoče vrednosti zapolnili s povprečnimi za tisto spremenljivko. Namen tipologije je bil ugotoviti, kako se občine razvrščajo glede na sposobnost upravljanja s prostorom in s tem izvajanja prostorske zakonodaje. Takšna razvrstitev občin je dobrodošel podatek za pripravljavce politik in predpisov na področju prostorskega načrtovanja in lokalne samouprave, saj pomaga optimizirati delovanje javne uprave in tako prispeva k vzpostavitvi želenega sistema prostorskega načrtovanja, ki upošteva danosti, trenutno stanje in potrebe. Dodatno smo preverili, ali obstaja povezava med velikostno in upravljavsko tipologijo občin, če torej trditev, da imajo manjše občine tudi slabšo upravljavsko sposobnost, drži.

\section{Rezultati po izbranih kazalnikih}

Prvi kazalnik je ustreznost prebivalstvenemu zakonskemu kriteriju za nastanek občine, pri čemer smo ločili osnovni in pogojni kriterij. Nad osnovno prebivalstveno mejo 5.000 prebivalcev je skupaj 35 občin (63,6\%), med pogojno mejo 2.000 prebivalcev in osnovno mejo je 15 občin (27,3\%), torej skupaj $91 \%$ občin ustreza vsaj enemu od kriterijev ustanovitve. V javnosti prevladuje mnenje, da drobljenje občin, četudi ustrezajo vsaj pogojnemu kriteriju, znižuje sposobnosti občinskih uprav za izvajanje nalog (Bla- 
gajne in Šantej 2001; Ravbar in Bole 2002), zato so sodelujoči dodatno ocenili spremembo kakovosti prostorskega načrtovanja po odcepitvi. Takšnih občin je v vzorcu 29 , ena spremembe ni ocenila. Po mnenju štirinajstih občin se kakovost ni spremenila, za štiri se je zmanjšala, deset občin se je pohvalilo z dvigom upravljavske sposobnosti. Glede na ocene odcepitev ne vpliva nujno na izboljšanje sposobnosti, vendar prednosti novonastalih, največkrat prebivalstveno in površinsko manjših občin načrtovalci vidijo v zmanjšanju velikosti občine in boljšem poznavanju območja, hitrejšem reševanju problemov in uresničevanju razvojnih pobud, $\mathrm{v}$ večji pozornosti prostorskemu načrtovanju in novih $\mathrm{v}$ delovnih mestih, $\mathrm{v}$ enakopravnem vključevanju vseh naselij in v lastnih prostorskih aktih. Občine s slabšimi izkušnjami so omenile zmanjšanje kadrovske ustreznosti, saj ena oseba pokriva več področij in bolj površno kot prej, in uveljavljanje posamičnih interesov lokalnih veljakov, ko občinska uprava zaradi majhnosti ne zna celovito in kakovostno upravljati s prostorom.

Kadrovske rešitve za prostorsko načrtovanje so odvisne tudi od tipa uprave. Občine imajo bodisi enovito občinsko upravo brez notranje delitve na podenote ali oddelke - 32 občin ( $58 \%$ ) bodisi razdeljeno občinsko upravo z oddelki - 23 občin $(42 \%)$. Kljub jasni ločnici med tipoma imajo občine zelo različne organizacijske in kadrovske rešitve na področju prostorskega načrtovanja. Organiziranost uprav ni stalna, saj občina $\mathrm{z}$ novo sistematizacijo oddelek ukine, ga preimenuje $\mathrm{v}$ urad in dejavnosti urejanja prostora porazdeli med različnimi oddelki. Raznolikost rešitev smo analizirali s pregledom notranje organizacije občinske uprave za področje urejanja prostora.

Trideset občin $z$ enovito upravo ima sodelavce za urejanje prostora različno poimenovane glede na delovno mesto in področje. Poleg (višjega) referenta/sodelavca/svetovalca za okolje in prostor področje pokrivajo sodelavci za gospodarsko infrastrukturo, gospodarjenje s stavbnimi zemljišči, investicije, urbanizem in stavbna zemljišča, družbene dejavnosti ali pa so to svetovalci brez področja. Znotraj občine urejanje prostora pokrivajo še župan, tajnik občine in direktor občinske uprave, izven pa direktor javnega komunalnega podjetja in $\mathrm{v}$ štirih primerih zunanji občinski urbanist - prostorsko-načrtovalsko podjetje, kar ponazarja raznovrstnost kadrovskih rešitev. Osemnajst občin ima samostojen oddelek za okolje in prostor, dve občini sta ustanovili službo za urejanje prostora in varstvo okolja, dve urad za prostor. Nekaj občin izkorišča možnost zakona o lokalni samoupravi (2007) in so za področje urejanja prostora ustanovile skupno občinsko upravo. V skupne občinske uprave so vključene občine Ormož (tri občine), Mestna občina Ptuj (17 občin) in Lendava (tri občine), ki so hkrati vodje skupnih občinskih uprav, poleg drugih nalog zadolženih vsaj za občinsko inšpekcijo in redarstvo ter urejanje prostora.

Slika 2: Tip organizacije občinske uprave za področje prostorskega načrtovanja.

Glej angleški del prispevka.

Povprečna ocena kadrovske ustreznosti za urejanja prostora znaša 3,4 - nekje na meji med delno ustrezno in ustrezno. Največ občin je izbralo oceno ustrezno, in sicer 23, delno zadovoljnih je 20 občin, oceno neustrezno je podalo šest občin ( $11 \%)$. Zanimala nas je razlika v oceni kadrovske ustreznosti glede na tip uprave. Občine z enovito upravo so manj zadovoljne s kadrovsko "preskrbljenostjo« za potrebe urejanja prostora, saj jo je 31 občin povprečno ocenilo s 3,2 - delno ustrezno (mediana in modus oba 3 ), medtem ko je 23 občin z razdeljeno upravo bolj zadovoljnih s kadrovskimi rešitvami, povprečna ocena 3,7 - ustrezno (mediana in modus oba 4). Vidimo, da tip uprave vpliva na zadovoljstvo s kadrovsko oceno.

Število zaposlenih za prostorsko načrtovanje se med občinami precej razlikuje. Skupaj je v 55 občinah zaposlenih 220,5 osebe, brez Mestne občine Ljubljana z 42 zaposlenimi znaša vsota 178,5 osebe. $V$ povprečju so zaposlene štiri osebe. Največ občin (19) ima zaposleno eno osebo, sledi deset občin z dvema zaposlenima. V kadrovsko šibkejših občinskih upravah ena oseba poleg načrtovanja pokriva več področij, večje občine zaposlujejo v povprečju od 6 do 11 oseb.

Od sprejema ZUreP-1 leta 2003 je 20 občin odprlo nova delovna mesta, dve sta število delovnih mest zmanjšali. Novi delavci imajo različno izobrazbo in opravljajo različne naloge, na primer operativne gradbene zadeve, urejanje prometa, urbanizem in razvoj, pripravo OPN in drugo. Večina občin z novimi delovnimi mesti je prebivalstveno srednje velikih do velikih, kot so Jesenice, Zagorje ob Savi, Novo mesto, Postojna, Nova Gorica.

Potrebo po novih delovnih mestih je izrazilo 32 občin, ki skupaj potrebujejo 47 delovnih mest, od tega 19 občin eno, šest občin tri in štiri občine dve delovni mesti. Izračun ne pokaže povezave med tipom uprave/obstoječim številom zaposlenih in potrebo po delovnih mestih, saj nove delavce potrebujejo obči- 
ne $\mathrm{z}$ enovito/razdeljeno upravo in $\mathrm{z}$ manjšim/večjim številom zaposlenih. Po izobrazbi je najbolj zaželen arhitekt (8), sledi krajinski arhitekt, predstavniki drugih prostorskih strok in pravniki. Šestim občinam so pomembnejša znanja kot izobrazba novozaposlenih: sedem občin potrebuje lastnega občinskega urbanista, tri strokovnjaka za GIS, ostale administrativno pomoč, osebo za vzpostavitev in vzdrževanje evidenc, specialista za prostorsko pravo, pomoč pri koordinaciji med pogodbenimi pripravljavci in ministrstvi, revizorja za strokovno presojo prostorskih načrtov in odlokov ter nekoga s celovitim dojemanjem prostora in razvojnih rešitev. Nekateri rešitev namesto v novozaposlenih vidijo v boljši izobrazbi obstoječe delovne sile.

Podatki o deležu sredstev občinskega proračuna za dejavnost prostorskega načrtovanja so na voljo na spletni strani ministrstva za finance (2010). Izbrali smo funkcionalno klasifikacijo porabe sredstev, za katero so podatki na voljo za leta med 1999 in 2008. Primerljivost podatkov je zagotovljena s preračunom v delež celotnega občinskega proračuna. Za prikaz finančne porabe smo izbrali leto 1999 kot prvo leto $\mathrm{z}$ dostopnimi podatki, leto 2004 kot drugo leto po uveljavitvi ZUreP-1 (2003) in leto 2008 kot eno leto po sprejetju ZPNačrt (2007). Povprečen delež porabe na občino iz vzorca je bil leta 1999 2,44\%, leta 2004 $2,31 \%$ in leta $20081,23 \%$, ko se je poraba za prostorsko načrtovanje zmanjšala na samo 24.448.557 evrov. Primerjava s celotnim slovenskim povprečjem za leti 1999 in 2004 pokaže podpovprečno rabo vzorca, v letu 2008 mu je skoraj enaka. Po posameznih občinah so v letu 2008 za to dejavnost največ namenile Mirna Peč (8,7\%), Ribnica na Pohorju (3,5\%) in Metlika (2,8 \%), najmanj Mestna občina Ptuj in Slovenske Konjice $(0,1 \%)$ ter Šalovci z $0 \%$. Vrednost za leto 2008 je tudi vnesena v izračun tipologije.

Slika 3: Delež, ki so ga občine namenile za dejavnost prostorskega planiranja v letu 2008.

Glej angleški del prispevka.

Za finančni kazalnik se prav tako predpostavlja povezava $\mathrm{z}$ velikostjo občine in višino porabe. Izračun Pearsonovega koeficienta ne pokaže statistično pomembne povezanosti med številom prebivalcev in finančno porabo za prostorsko planiranje $(\mathrm{r}=-0,017 ; \mathrm{p}=0,901)$, prav tako je ni med površino in porabo $(r=-0,170, p=0,214)$ ali tipom uprave in porabo $(\rho=-0,211, p=0,121)$.

Na upravljavsko sposobnost urejanja prostora vpliva tudi razumevanje prostorske zakonodaje. Petnajst predstavnikov občin ni imelo težav $z$ razumevanjem ZPNačrt, ostalih 40 je izpostavilo vsaj en problem. Največkrat so bile izbrane možnosti nejasna razdelitev nalog (21), nejasno in zapleteno besedilo (20), nedoslednost določil in nalog (13) ter neustreznost izrazov (9). Najmanj težav je bilo s slogovnim razumevanjem besedila, saj so pravnih besedil občine vajene $\mathrm{z}$ drugih področij. Pod drugo so občine izpostavile opredelitev nekaterih pojmov, kot so odprti prostor, razpršena gradnja in razpršena poselitev.

$\mathrm{V}$ urejanje prostora se vključuje veliko deležnikov $\mathrm{z}$ različnimi interesi in vplivi na končni prostorski poseg, ki so jih občine ocenile na petstopenjski intervalni lestvici in podale opis v primeru deležnikov z velikim in zelo velikim vplivom. Debelina puščice na sliki 4 premosorazmerno prikazuje numerično ocenjeno velikost vpliva. Največji vpliv na vsebino prostorskih načrtov in prostorsko-razvojne odločitve občin imajo sektorska ministrstva. Občine njihov vpliv opisujejo kot negativen, zlasti v primeru smernic, s katerimi ministrstva kot nosilci smernic urejanja prostora ugotavljajo usklajenost osnutkov in predlogov OPN z državnimi usmeritvami in podajajo predloge za upoštevanje pobud $\mathrm{z}$ namenom varovanja prostora. Vloge smernic $\mathrm{v}$ postopku priprave OPN vsi deležniki ne razumejo enako, zato sektorska ministrstva izkoriščajo moč, da s področno zakonodajo namesto občin krojijo lokalno prostorsko politiko.

\section{Slika 4: Prikaz velikosti vpliva posameznih deležnikov na prostorski razvoj občine.}

Glej angleški del prispevka.

Približno enako velik vpliv si delijo MOP, župan, investitorji, občinski svet in kot zadnji v tej skupini oddelek za okolje in prostor. MOP kot nosilec urejanja prostora podaja smernice za poselitev, ugotavlja usklajenost OPN z državnimi usmeritvami ter odloča v postopku priprave OPN. Župan je glavni usmerjevalec razvoja na občinski ravni, nekdo ga je imenoval kar za glavnega prostorskega načrtovalca in urbanista, saj poda končno odločitev glede prostorskih posegov, sprejema prostorskih aktov, območij širjenja in dopustnosti gradenj. $\mathrm{V}$ nekaterih občinah imajo z županom pozitivne izkušnje, saj razume pomen prostora, zagotavlja ustrezne kadrovske rešitve, korektno, plodno in odgovorno sodeluje pri pripravi aktov ter skupaj z načrtovalskim oddelkom ali občinskim svetom predlaga utemeljene rešitve. Zaradi odvisnosti od 
volivcev včasih sprejme rešitve $\mathrm{v}$ nasprotju s stroko in zakonodajo, s čimer ustreže investitorjem - volivcem, ki pritiskajo na župana in vodilne, da bi podprli izvedbo njihovih projektov, na primer gradnjo stanovanjskih sosesk.

Občinski svet je poleg župana najvišji občinski organ z odločevalsko močjo, saj sprejema akte in $\mathrm{z}$ amandmaji tudi vpliva na njihovo končno vsebino, daje predloge za razvoj, določa prostorske cilje, nemalokrat zaradi svoje politične moči tudi »nagaja « - odloča v skladu z lastnimi interesi in preprečuje izvedbo določenih projektov. Občinski planerski oddelek vodi postopek priprave prostorskih aktov ter kot edini s pregledom nad dejanskim stanjem $v$ prostoru skrbi za njihovo kakovost in strokovnost. $V$ procesu priprave veliko sodeluje z zunanjim izdelovalcem, občani in tudi podaja projektne ideje, vendar nima odločevalske moči in zato težko doseže kompromisno rešitev med stroko in politiko.

Niti majhen niti velik vpliv imajo lokalni prebivalci in okoljevarstvene nevladne organizacije. Prebivalci se $\mathrm{v}$ prostorsko-načrtovalski proces vključijo $\mathrm{v}$ javni razgrnitvi in obravnavi, ko poskušajo vplivati na razvoj, vendar večinoma $\mathrm{z}$ namenom, da bi zadovoljili potrebo po zazidavi lastne parcele. $V$ primeru organiziranega nastopa, na primer okoljskih in drugih nevladnih organizacij, lažje dosežejo svoje, čeprav je še vedno težko opredeliti, čigav interes zares branijo - okolja, stroke, javnosti ali posamični interes, ki je prerasel $\mathrm{v}$ javnega.

Pogostost sodelovanja med izbranimi deležniki je manjša od predvidene. S štirimi od devetih deležnikov - Službo Vlade RS za lokalno samoupravo in regionalni razvoj, MJU, lokalnimi NVO in MG - občine pri reševanju prostorskih problemov v povprečju sodelujejo le izjemoma. S sosednjimi občinami, RRA, MKGP ter MZP se občine posvetujejo včasih, le z MOP sodelujejo pogosto. Poleg deležnikov s seznama so občine izpostavile še druge, lokalne deležnike: Zavod za varstvo narave, Zavod za varstvo kulturne dediščine, gospodarske javne službe in čezmejne občine, s katerimi sodelujejo pogosto. Poleg pogostosti so občine ocenile kakovost sodelovanja. Večinoma občine dobro sodelujejo z vsemi deležniki, najvišjo oceno so dobile sosednje občine in MZP, sledijo RRA, lokalne NVO in Služba Vlade RS za lokalno samoupravo in regionalni razvoj. Kakovost sodelovanja z drugimi deležniki ni niti dobra niti slaba, najnižjo oceno je dobilo MKGP, in sicer na meji med slabo in srednje dobro kakovostjo sodelovanja.

Stopnjo sodelovanja javnosti smo merili na petstopenjski lestvici Mednarodnega združenja za sodelovanje IAP2 (Umanotera poroča 2007). Po predvidevanjih je sodelovanje na zelo nizki ravni, v povprečju občine uporabljajo posvetovanje, ko javnost obvestimo o načrtih in jo povabimo k pisnemu/ustnemu posredovanju stališč in želja v okviru javnih razprav, kasneje pa jo obvestimo o vplivu prispevkov na končno odločitev. Sledi najnižja stopnja - stopnja informiranja, ko javnost le obvestimo o načrtih in projektih prostorskega razvoja ter omogočimo razumevanje problema in alternativnih rešitev. Le šest občin se je odločilo za aktivnejše sodelovanje javnosti s pomočjo delavnic že v samem začetku načrtovalskega procesa ali z vzpostavitvijo partnerskega sodelovanja s skupnostjo. Dodatno smo preverili povezanost med številom zaposlenih na področju urejanja prostora in stopnjo sodelovanja. Povezava statistično ni pomembna $(\rho=-0,193 ; p=0,183)$, tako da večje število zaposlenih na občini ne zagotavlja nujno tudi višje stopnje sodelovanja javnosti.

Slika 5: Prikaz pogostosti in kakovosti sodelovanja med občino in ostalimi deležniki v sistemu prostorskega planiranja pri reševanju prostorskih problemov.

Glej angleški del prispevka.

\section{Tipologija občin}

Za izbrane kazalnike upravljavske sposobnosti nas je zanimalo, ali in kako se občine povezujejo v skupine. $\mathrm{Z}$ metodo razvrščanja $\mathrm{v}$ skupine smo ločili tri skupine, in sicer občine s slabšimi pogoji za izvajanje prostorske zakonodaje (37 občin), občine z boljšimi pogoji (17 občin) in Mestno občino Ljubljana kot občino z najboljšimi pogoji. Po predvidevanjih so se v skupino s slabšimi pogoji uvrstile občine $\mathrm{z}$ enovito občinsko upravo, manjšim številom zaposlenih, ki so nastale z odcepitvijo, nimajo oddelka za prostorsko planiranje ali svojega občinskega urbanista. Kadrovsko ustreznost za prostorsko načrtovanje ocenjujejo kot delno neustrezno, v povprečju je zaposlenih 1,6 delavca. Dve tretjini občin s slabšimi pogoji potrebujeta novo delovno silo. V skupini z boljšimi pogoji vse občine dosegajo osnovni zakonski kriterij ustanovitve, štiri so mestne. Večina ima razdeljeno upravo z oddelkom za okolje in prostor ali vodijo skupno upravo ter so obstajale že pred delitvijo na nove občine. Poleg kadrovskih rešitev občine jasno ločujejo še kazal- 
niki poraba financ, pogostost sodelovanja v načrtovalskem postopku in deležniki z vplivom na razvoj. Pri povprečni porabi financ je rezultat mogoče drugačen od pričakovanega, saj boljše občine porabijo pol manj denarja za prostorsko načrtovanje $-0,87 \%$ občinskega proračuna, a so za oceno bolj zadovoljne s svojo kadrovsko preskrbljenostjo. Pogostost sodelovanja je med skupinama ponovno različna. Največ občin $\mathrm{z}$ boljšimi pogoji pogosto sodeluje $\mathrm{z}$ ministrstvo za okolje in prostor ter včasih $\mathrm{z}$ regionalno razvojno agencijo, sosednjimi občinami, ministrstvom za promet in ministrstvom za gospodarstvo, največ »slabših občin " pa pogosto sodeluje le z ministrstvom za promet in RRA-jem, včasih tudi z drugimi deležniki, kot so sosednje občine, ministrstvo za okolje in prostor, ministrstvo za kmetijstvo, gozdarstvo in prehrano. $V$ povprečju je obseg sodelovanja občin s slabšimi pogoji manjši od občin $z$ boljšimi pogoji. Tudi po vplivu posameznih deležnikov na prostorski razvoj se skupini ločita med seboj. V občinah s slabšimi pogoji najbolj vplivajo sektorska ministrstva, MOP, župan, oddelek in občinski svet, medtem ko imajo v občinah z boljšimi pogoji okoljske nevladne organizacije in MOP ter prebivalci manjši vpliv, ostali večjega. V obeh skupinah je približno ena petina občin brez večjega vpliva deležnikov razen MOP-a z velikim ter župana, investitorjev in občinskega sveta s srednjevelikim vplivom.

\section{Slika 6: Tipologija občin glede na upravljavsko sposobnost.}

Glej angleški del prispevka.

Ostali kazalniki (razumevanje zakonodaje, potreba po delovni sili, sodelovanje javnosti in kakovost sodelovanja) skupin ne ločujejo jasno med seboj oziroma je rezultat drugačen od pričakovanega. Tako ima glede na delež težave z razumevanjem manj občin (32\%) s slabšim socialnim kapitalom kot tistih z boljšimi pogoji (16\%). Ocenjena raven sodelovanja javnosti je pri »slabših občinah « višja, saj nekatere dosegajo raven vključevanja in sodelovanja, v večini pa je javnost vključena le v okviru posvetovanja. Potreba po delovni sili in kakovost sodelovanja sta pri obeh skupinah ocenjeni podobno: občine obeh skupin potrebujejo kadrovske okrepitve; za polovico je dobro sodelovanje z vsemi deležniki, razen z MJU, NVO, MZP in MG, s katerimi je povprečno, z MKGP pa slabo. Tretjina občin sodeluje dobro z vsemi, razen z ministrstvom za kmetijstvo, gozdarstvo in prehrano, ministrstvom za javno upravo, lokalnimi nevladnimi organizacijami in ministrstvom za gospodarstvo.

Po upravljavski sposobnosti izstopa Mestna občina Ljubljana z razdeljeno upravo in oddelkom za okolje in prostor z 42 zaposlenimi, ki letno porabi 1,68 \% občinskega proračuna. Kljub ustrezni oceni kadrovskih pogojev vseeno potrebujejo dodatno zaposlene. $Z$ javnostjo sodelujejo na ravni posvetovanja, $\mathrm{z}$ drugimi deležniki sodelujejo pogosto in dobro, razen z ministrstvi, s katerimi imajo težave tudi druge občine. Največji vpliv na razvoj MOL-a imajo občinski svet, sektorska ministrstva, investitorji, oddelek in župan.

Slika 7: Prikaz odvisnosti tipologije upravljavske sposobnosti od velikostne tipologije.

Glej angleški del prispevka.

Primerjava upravljavske in velikostne tipologije - izračun $\chi^{2} z$ vrednostjo 75,332 in 0-odstotnim statističnim tveganjem - je pokazal, da sta tipologiji odvisni ena od druge, zato v občinah, ki so različno "velike«, najdemo različno upravljavsko sposobnost. Močno povezanost med uvrstitvijo občine v upravljavsko in velikostno tipologijo je dodatno dokazal izračun Cramerjevega koeficienta $\mathrm{z}$ vrednostjo 0,828 in izris grafikona frekvenčne porazdelitve.

\section{Sklep}

Opravljena analiza je pokazala, da imajo nekatere občine boljše pogoje za izvajanje prostorske zakonodaje kot druge in je zato njihova sposobnost urejanja prostora večja. Dokazali smo povezavo med velikostjo občine in pogoji izvajanja prostorske zakonodaje, vendar pa podrobnejša analiza po posameznih kazalnikih pokaže določene nepričakovane razlike, zato občine težko nedvoumno delimo na »slabe in dobre«. Na primer, povprečen delež porabljenih sredstev občinskega proračuna je v občinah s slabšimi pogoji večji kot v skupini boljših. Kazalniki, ki občine dobro ločujejo, so kadrovske rešitve občine, poraba financ, pogostost sodelovanja s posameznimi deležniki in moč vpliva posameznih skupin prebivalcev na prostorski razvoj. Iz analize sodelovanja sklepamo, da je izvajanje zakonodaje lažje, če imamo na voljo veliko število zaposlenih, razdeljeno občinsko upravo, več in pogosteje sodelujemo z vsemi deležniki, še zlasti pa 
z ministrstvom za okolje in prostor, zagotavljamo čim večjo kakovost sodelovanja in smo odprli nova delovna mesta za to področje. Kljub nekaterim spremembam na bolje sposobnost občin še vedno ne ustreza zahtevnim nalogam prostorske zakonodaje, kar ponovno ponazarja neupoštevanje stanja pri pripravi novega predpisa. Slabše sodelovanje med sektorskimi ministrstvi kaže na zakonsko neurejeno sodelovanje državnih deležnikov pri urejanju prostora. Čeprav zakonodaja na eni strani zahteva hitro in učinkovito ravnanje občin pri izvajanju posegov v prostor, ZPNačrt za razliko od ZUreP-1 ne predvideva posebnih in obveznih kadrovskih rešitev, na primer obveznega občinskega urbanista, večjega obsega sodelovanja javnosti, in ne opredeljuje jasno nalog deležnikov.

Izdelana tipologija kaže, da je v vzorcu še vedno več občin s slabšimi kot z boljšimi pogoji, zato je potrebno izboljšanje upravljavske sposobnosti. Izboljšanje lahko dosežemo na več načinov. Glede na manjšo učinkovitost zakonske vpeljave občinskega urbanista, ki ga je zaposlilo le nekaj občin, in glede na pozitivne premike, ki se dogajajo v sistemu brez zakonodajnih obvez, je smiselno sposobnost občin krepiti z mehkejšimi ukrepi. Ob predpogoju, da se na državni ravni v politiki prepozna pomen prostorskega načrtovanja, predlagamo intenzivno usposabljanje sedanje delovne sile o novejših pristopih k prostorskemu načrtovanju in zlasti njegovih pravnih vidikih, večje število zaposlenih, pri čemer mora finančno šibkim občinam pri tem pomagati država, višjo stopnjo sodelovanja javnosti in večji obseg sodelovanja med vsemi deležniki, saj sedaj nekatere občine $\mathrm{z}$ drugimi sodelujejo le redko. Takšen način urejanja prostora zapovedujejo sodobni tipi prostorskega načrtovanja, kot je sodelujoče načrtovanje (Innes 1996), ki se odmikajo od zavezujočih formalnih postopkov $\mathrm{k}$ vzpostavitvi dialoga in vključitvi več družbenih skupin v iskanje ustrezne prostorske rešitve. Bolj kot število zaposlenih je pomembna sposobnost načrtovalcev, saj se njihova vloga spreminja. Niso več le izdelovalci načrtov, ampak vse bolj posredniki (Kitchen 2006), ki morajo poznati več kot le vsebino prostorskega zakona. Nezakonske rešitve slabosti sistema oziroma okrepitev upravljavske sposobnosti je predlagala tudi ESPON-ova študija (2006), po kateri je treba izboljšati vertikalno sodelovanje med državno in lokalno ravnjo, ki se je za šibko izkazalo tudi v naši raziskavi. Prav tako se je potrdilo, da zaradi nezadostne vključenosti izvajalcev v proces priprave novega predpisa zakonodaja ni predvidela ustreznih rešitev za njeno izvajanje, saj občine še naprej nimajo zadostnih pogojev za izvajanje, zato prostorsko načrtujejo na različni osnovi in v različnem obsegu. Poleg obravnavane upravljavske sposobnosti občin vplivajo na kakovost prostorskega načrtovanja tudi dejavniki, ki niso neposredno povezani z upravljanjem, na primer obseg in vsebina strokovnega znanja prostorskih načrtovalcev ali prostorska kultura in vrednote prebivalcev in deležnikov. Te dejavnike lahko zaobjame celovita sistemska analiza, medtem ko smo se v tem članku osredotočili na neposreden, zakonsko urejen in pogojen upravljavski vidik.

\section{Literatura}

Glej angleški del prispevka. 